\title{
Discrimination of 3 dominant mangrove species from the Pacific coast of Mexico by spectroscopy on intact leaves
}

\section{Discriminación de 3 especies dominantes de mangle de la costa mexicana del Pacífico mediante técnicas espectroscópicas de hoja intacta}

\author{
Francisco Flores-de-Santiago $^{1 *}$, John M Kovacs $^{2}$, Francisco Flores-Verdugo ${ }^{3}$ \\ ${ }^{1}$ Instituto de Ciencias del Mar y Limnología, Unidad Académica Procesos Oceánicos y Costeros, Universidad \\ Nacional Autónoma de México, A.P. 70-305, Av. Universidad 3000, Ciudad Universitaria, Coyoacán, \\ CP 04510, Mexico City, Mexico. \\ 2 Department of Geography, Nipissing University, 100 College Drive, North Bay, Ontario, P1B 8L7, \\ Canada. \\ ${ }^{3}$ Instituto de Ciencias del Mar y Limnología, Unidad Académica Mazatlán, Universidad Nacional \\ Autónoma de México, Av. Joel Montes Camarena, s/n, CP 82040, Mazatlán, Sinaloa, Mexico.
}

*Corresponding author. E-mail: floresdesantiago@gmail.com; ffloresd@cmarl.unam.mx

\begin{abstract}
Spectral discrimination of mangrove leaves is the first step in classifying remotely sensed imagery of mangrove forests. The objective of this study was to analyze spectroscopic data on leaves from the upper and lower parts of mangrove canopies to discriminate species and physiognomic types. Leaf samples from the upper and lower parts of the canopies of 3 mangrove species (Avicennia germinans, Laguncularia racemosa, and Rhizophora mangle) in 2 physiognomic types (basin and fringe) were collected during 2 seasons (dry and rainy). Probability distribution and first-derivative plots were generated for every wavelength $(450-1,000 \mathrm{~nm})$ detected in all samples. With the plots, optimal wavelengths were selected and subsequently verified with a canonical discriminant analysis. Results indicated that all species in basin mangrove forests showed a unique distinction between the upper and lower leaves during the dry season. By contrast, species in fringe mangrove forests did not show this difference during both seasons. Optimal wavelengths for species discrimination were located between 540-560 nm and 700-720 nm, which correspond to the green and red-edge wavebands, respectively. Future studies using remote sensing data with the aforementioned wavebands can be conducted to discriminate physiognomic mangrove forest types and to increase accuracy in the classification of mangroves at the canopy level on the Pacific coast of Mexico.
\end{abstract}

Key words: Laguncularia racemosa, Rhizophora mangle, Avicennia germinans, water stress.

RESUMEN. La discriminación foliar de mangles por medio de técnicas espectroscópicas es el primer paso para clasificar imágenes de sensores remotos de bosques de mangle. El objetivo de este estudio fue analizar datos espectroscópicos de hojas de la parte superior y la parte inferior del dosel arbóreo para poder discriminar especies y condiciones fisiognómicas en un bosque de mangle. Muestras de hojas de la parte superior y la parte inferior de los doseles de 3 especies de mangle (Avicennia germinans, Laguncularia racemosa y Rhizophora mangle) en 2 condiciones fisiognómicas (cuenca y borde) fueron recolectadas durante 2 temporadas (estiaje y lluvia). Gráficas de distribución de probabilidad y de primera derivada fueron generadas para cada una de las longitudes de onda (450-1,000 nm) de todas las muestras. Con base en las gráficas, las longitudes de onda óptimas fueron seleccionadas y, posteriormente, comprobadas con un análisis discriminante canónico. Los resultados indicaron que todas las especies de mangle tipo cuenca mostraron una separación única entre las hojas de la parte superior y la parte inferior del dosel durante la temporada de estiaje. Por el contrario, los mangles tipo borde no presentaron esta diferencia durante ambas temporadas. Las longitudes de onda óptimas para la discriminación de especies fueron localizadas entre 540-560 nm y 700-720 nm, correspondientes a las bandas verde y borde del rojo, respectivamente. Estudios posteriores con datos de sensores remotos que contengan dichas longitudes de onda pueden ser empleados para discriminar condiciones fisiognómicas en bosques de mangle e incrementar la precisión en clasificaciones de mangles a nivel de dosel en la costa mexicana del Pacífico.

Palabras clave: Laguncularia racemosa, Rhizophora mangle, Avicennia germinans, estrés hídrico.

\section{INTRODUCTION}

Despite the constant analysis and interpretation of hyperspectral and spectroscopic data for different plant species, there are several difficulties with the identification of flora due to a combination of factors such as variability in atmospheric conditions (Jensen 2005), soil humidity and flooding

\section{INTRODUCCIÓN}

A pesar del constante análisis e interpretación de datos hiperespectrales y espectroscópicos de diferentes especies vegetales, la identificación de flora tropical presenta varias dificultades debido a una combinación de factores tales como variabilidad en las condiciones atmosféricas (Jensen 2005), 
(Guo et al. 2017a), angle of incidence (Kuenzer et al. 2011), choice of optimal vegetation indices (Bannari et al. 1995), spatial resolution (Wulder et al. 2004), data availability for remote areas (Pettorelli et al. 2014), seasonal phenological changes (Flores-de-Santiago et al. 2013a), forest composition and structure (Barbosa et al. 2014), choice of method of analysis (Dronova 2015), and availability of minimum sample size (Congalton 1991). Consequently, spectroscopic results for tropical forests show high variability (Friess and Webb 2013), and spectral signatures are not unique at the species level (Flores-de-Santiago et al. 2016). However, in recent years, new sensors and methods that collect information with high spectral and spatial resolution have been developed (Guo et al. 2017b, Tian et al. 2017).

Mangrove forests are intertidal habitats located along tropical and subtropical zones (Tomlinson 1994). They are considered one of the most productive ecosystems in the planet because they maintain ecological balance in coastal lagoons (Agraz-Hernández et al. 2011), deltas (Nam et al. 2016), and nearby ecosystems such as seagrass beds (Chen et al. 2017) and coral reefs (Martin et al. 2015). Mangrove forests are important for local communities because they help prevent coastal erosion, benefit fisheries, and provide construction material (Mukherjee et al. 2014). The ecological importance of these ecosystems can also be associated with other factors such as primary production (high) (Komiyama et al. 2008), mitigation of global warming effects (Gilman et al. 2008), and regulation of the nutrient cycle (Keuskamp et al. 2015), in addition to being an important source of organic matter for local fauna (Nagelkerken et al. 2008). Despite their ecological and economic importance, $40 \%$ of mangrove species are currently threatened (Polidoro et al. 2010) by aquaculture-related activities (Duncan et al. 2016), deforestation (Duke et al. 2007), hydrocarbon pollution (Duke 2016), sea level rise (Lovelock et al. 2015), and hydrological changes (Flores-de-Santiago et al. 2017).

Mangrove forests reach maximum development at tropical latitudes where temperature variability in the environment is constant throughout the year $\left(20 \pm 5^{\circ} \mathrm{C}\right)$ (Tomlinson 1994), freshwater sources are abundant, and interstitial salinity is thus between 5 and 30 (Godoy and De Lacerda 2015). Conversely, estuaries and coastal lagoons in subtropical latitudes (i.e., arid regions) differ from their tropical counterparts in 2 general aspects. Firstly, river runoff is intense and constant during the short rainy season but inexistent during a considerable length of time (dry season). Secondly, there are dry floodplains separating terrestrial vegetation from mangrove forests. Both aspects result in hypersalinity of interstitial water (>80) for most of the year (Ridd and Stieglitz 2002). Hence, 2 mangrove physiognomic types are commonly found at subtropical latitudes: fringe mangrove forests (i.e., healthy) along the tidal channel and basin mangrove forests (stressed) in areas where water exchange is minimum or inexistent (Monroy-Torres et al. 2015). Basin mangroves tend to be short (i.e., chaparral) and, generally, form gaps in the forest humedad/inundación del suelo (Guo et al. 2017a), ángulo de incidencia (Kuenzer et al. 2011), selección de índices de vegetación óptimos (Bannari et al. 1995), resolución espacial (Wulder et al. 2004), disponibilidad de datos para zonas remotas (Pettorelli et al. 2014), cambios fenológicos temporales (Flores-de-Santiago et al. 2013a), composición y estructura del bosque (Barbosa et al. 2014), selección del método de análisis (Dronova 2015) y disponibilidad del tamaño mínimo de muestra (Congalton 1991). Como consecuencia, los resultados espectroscópicos para bosques tropicales presentan una variabilidad elevada (Friess y Webb 2013), y las firmas espectrales no son únicas a nivel de especie (Flores-de-Santiago et al. 2016). Sin embargo, durante los últimos años se han desarrollado sensores y métodos nuevos que son capaces de recolectar información con resolución espectral y espacial alta (Guo et al. 2017b, Tian et al. 2017).

Los bosques de mangle son hábitats intermareales localizados a lo largo de zonas tropicales y subtropicales (Tomlinson 1994). Son considerados uno de los ecosistemas del planeta más productivos, ya que mantienen el equilibrio ecológico en lagunas costeras (Agraz-Hernández et al. 2011) y deltas (Nam et al. 2016), al igual que en ecosistemas cercanos como pastos marinos (Chen et al. 2017) y arrecifes de coral (Martin et al. 2015). Los bosques de mangle son importantes para comunidades locales porque proporcionan protección contra la erosión costera, beneficios para pesquerías y material de construcción (Mukherjee et al. 2014). La importancia ecológica de estos ecosistemas puede ser también relacionada con factores como producción primaria (elevada) (Komiyama et al. 2008), mitigación de los efectos del calentamiento global (Gilman et al. 2008) y regulación del ciclo de nutrientes (Keuskamp et al. 2015), además de que son una fuente importante de materia orgánica para la fauna local (Nagelkerken et al. 2008). A pesar de su importancia ecológica y económica, el $40 \%$ de las especies de mangle se encuentran amenazadas (Polidoro et al. 2010) por actividades relacionadas con la acuacultura (Duncan et al. 2016), la deforestación (Duke et al. 2007), la contaminación por hidrocarburos (Duke 2016), el incremento en el nivel del mar (Lovelock et al. 2015) y los cambios hidrológicos (Flores-de-Santiago et al. 2017).

Los bosques de mangle alcanzan su desarrollo máximo en latitudes tropicales donde la variabilidad en la temperatura ambiental es constante a lo largo del año $\left(20 \pm 5^{\circ} \mathrm{C}\right)$ (Tomlinson 1994), la fuente de agua dulce es abundante y la salinidad intersticial es, consecuentemente, entre 5 y 30 (Godoy y De Lacerda 2015). Por el contrario, los estuarios y las lagunas costeras en latitudes subtropicales (i.e., regiones áridas) difieren de sus contrapartes tropicales en 2 aspectos generales. En primer lugar, la escorrentía es intensa y puntual durante la corta temporada de lluvia, pero es nula durante un lapso de tiempo considerable (estiaje). En segundo, hay llanuras de inundación secas que separan la vegetación terrestre del bosque de mangle. Ambos aspectos resultan en la hipersalinidad del agua intersticial $(>80)$ la mayor parte del 
canopy; as a result, they show variability in the chemical composition of their leaves when compared with the leaves of the same species in the fringe mangrove community (Floresde-Santiago et al. 2012).

The main advantage of acquiring spectroscopic data for ecological studies of mangrove forests is that spectral information can be obtained quickly. This advantage increases the possibility of analyzing ties between spectroscopic data and biochemical variables using different statistical approaches (Flores-de-Santiago et al. 2016). However, spectral variability in the different mangrove species depends on many biochemical and structural factors. For example, the content and composition of photosynthetic pigments (chlorophyll $a$ [chla], chlorophyll $b[\mathrm{chl} b]$ ) affect the visible part of the electromagnetic spectrum (i.e., 400-700 nm) (Flores-de-Santiago et al. 2013b). In addition, nitrogen content (Zhang et al. 2013), leaf humidity, and air spaces in leaf structure can affect spectral response in the near-infrared (i.e., $700-1,300 \mathrm{~nm}$ ) and shortwave infrared (i.e., 1,300-2,500) regions (Danson 1995).

Given the anthropogenic pressure on mangrove forests, especially in arid regions where environmental conditions are unfavorable, there is constant need for the development of efficient techniques to readily obtain information for the protection and management of these forests. Accordingly, conservation programs should include an optimal spectral analysis to determine mangrove forest distribution, species composition, and health condition. For example, spectroscopic studies on mangrove forests have been divided into 2 main fields: (1) estimation of photosynthetic pigments and (2) discrimination at the species level. With respect to the former, Zhang et al. (2012) carried out a comparative analysis between 5 vegetation indices obtained from spectroscopic $(350-2,500 \mathrm{~nm})$ and pigment (chla, chlb, and total carotenoids) data for the black mangrove (Avicennia germinans) under 3 conditions (stressed, dwarf, and healthy) and the red mangrove (Rhizophora mangle) under 2 conditions (stressed and healthy). Their results indicated maximum estimation of chla and chlb at wavelengths near the red edge $(700-715 \mathrm{~nm})$ and of total carotenoids at $510 \mathrm{~nm}$. Flores-de-Santiago et al. (2013a) implemented a principal component analysis using 35 vegetation indices to estimate chla in a sample that comprised 3 subtropical mangrove species. Their results revealed a maximum chla estimation with the Vog1 vegetation index, which uses wavelengths near the red edge (740 and $720 \mathrm{~nm}$ ). Pastor-Guzman et al. (2015) estimated chlorophyll contents in 4 tropical mangrove species from the Gulf of Mexico during the cold-front season using 21 vegetation indices obtained from spectroscopic data $(350-2,500 \mathrm{~nm})$. Their results indicated that it is possible to estimate chlorophyll contents using the red-edge wavelengths $(705-753 \mathrm{~nm})$ and to extrapolate this estimation to areas of interest using Landsat 8 images. Heenkenda et al. (2015) estimated chlorophyll content at the mangrove forest level in Australia using field measurements and a WorldView-2 image with high spatial resolution. Their results indicated that it is possible to estimate chlorophyll año (Ridd y Stieglitz 2002). Por lo tanto, en latitudes subtropicales es común encontrar 2 condiciones fisiognómicas de mangle, las cuales incluyen una comunidad tipo borde (i.e., saludable) a lo largo del canal de mareas y una comunidad tipo cuenca (estresada) en zonas donde el intercambio de agua es de mínimo a nulo (Monroy-Torres et al. 2015). La comunidad tipo cuenca tiende a ser de menor altura (i.e., chaparral) y, por lo general, presenta huecos en el dosel forestal; por tanto, muestra variabilidad en la composición química de las hojas cuando estas son comparadas con las hojas de las mismas especies de la comunidad tipo borde (Floresde-Santiago et al. 2012).

La ventaja principal de adquirir datos espectroscópicos para estudios ecológicos de bosques de mangle es la rápida obtención de información espectral. Esta ventaja aumenta la posibilidad de analizar enlaces entre datos espectroscópicos y variables bioquímicas mediante diversas aproximaciones estadísticas (Flores-de-Santiago et al. 2016). Sin embargo, la variabilidad espectral de las diferentes especies de mangle depende de varios factores bioquímicos y estructurales. Por ejemplo, el contenido y la composición de los pigmentos fotosintéticos (clorofila $a$ [chla], clorofila $b[\operatorname{chl} l b]$ ) afectan la parte visible del espectro electromagnético (i.e., 400-700 nm) (Flores-de-Santiago et al. 2013b). Además, el contenido de nitrógeno (Zhang et al. 2013), la humedad de las hojas y la presencia de espacios con aire dentro de la estructura de la hoja pueden afectar la respuesta espectral en la región del infrarrojo cercano (i.e., $700-1,300 \mathrm{~nm}$ ) y del infrarrojo de onda corta (i.e., 1,300-2,500) (Danson 1995).

Debido a la presión antropogénica hacia los bosques de mangle, con particular énfasis en regiones áridas donde las condiciones ambientales no son favorables, existe una necesidad constante de desarrollar técnicas eficientes para obtener información de manera rápida para la protección y el manejo de estos bosques. Como consecuencia, los programas de conservación deben incluir un análisis espectral óptimo para determinar la distribución del bosque de mangle, la composición de especies y la condición de salud. Por ejemplo, los estudios espectroscópicos de bosques de mangle se han dividido en 2 áreas principales: (1) estimación de pigmentos fotosintéticos y (2) discriminación a nivel de especie. Dentro de la primer área, Zhang et al. (2012) efectuaron un análisis comparativo entre 5 índices de vegetación provenientes de datos espectroscópicos $(350-2,500 \mathrm{~nm})$ y datos de pigmentos (chla, chlb y carotenoides totales) de mangle negro (Avicennia germinans) en 3 condiciones (estresado, enano y saludable) y de mangle rojo (Rhizophora mangle) en 2 condiciones (estresado y saludable). Sus resultados denotaron una estimación máxima de chla y chlb en las longitudes de onda cercanas al borde del rojo (700-715 nm) y de carotenoides totales a $510 \mathrm{~nm}$. Flores-de-Santiago et al. (2013a) implementaron un análisis de componentes principales utilizando 35 índices de vegetación para estimar la chla en una muestra compuesta de 3 especies de mangle subtropical. Sus resultados revelaron una estimación máxima de chla con el índice de vegetación 
contents at the forest canopy level using the red $(630-690 \mathrm{~nm})$, red-edge (705-740 nm), near-infrared $1(770-895 \mathrm{~nm})$, and near-infrared 2 (860-900 nm) bands. Flores-de-Santiago et al. (2016) estimated pigment contents (chla, chlb, total carotenoids) with spectroscopic data (350-1,000 nm) using correlograms for 3 subtropical mangrove species during 2 seasons (rainy and dry). Their results indicated differences in pigment content estimates that depended on the season and the species.

Unlike the numerous studies on the estimation of photosynthetic pigment content, studies on the discrimination of species using spectroscopic data are scarce. For example, Vaiphasa et al. (2005) analyzed spectroscopic data (3502,500 $\mathrm{nm}$ ) for 16 tropical mangrove species in Thailand using probability distribution plots (analysis of variance [ANOVA]) and the Jeffries-Matusita distance and suggested that the 16 mangrove species can be classified according to 4 spectral regions located at 720,1,277, 1,415, and 1,644 $\mathrm{nm}$. Wang and Sousa (2009) studied spectroscopic variations (350-2,500 nm) in 3 tropical mangrove species from Panama using probability distribution plots (ANOVA) and a linear discriminant analysis and made discriminations between the 3 species using the $780,790,800,1,480,1,530$, and $1,550 \mathrm{~nm}$ wavelengths. Panigrahy et al. (2012) used probability distribution plots (ANOVA) and a factor analysis with spectroscopic data (3502,500 $\mathrm{nm}$ ) on 4 tropical mangrove species from India and made discriminations between the 4 species with data from the red, near-infrared, and mid-infrared wavebands. Zhang et al. (2014) applied a principal component analysis and a discriminant analysis to spectroscopic data $(350-2,500 \mathrm{~nm})$ on 3 subtropical mangrove species during the dry season and suggested maximum species discrimination at the 520, 560, 650, $710,760,2,100$, and 2,230 $\mathrm{nm}$ wavelengths.

Most spectroscopic studies have focused on analyzing mangrove species during a single season without taking into account the vertical distribution of leaves in the forest canopy. The vertical distribution of photosynthetic pigments is variable depending on the season, species, and physiognomic distribution (Flores-de-Santiago et al. 2012), and we therefore assume that the intensity of the spectroscopic signal presents seasonal variability. Thus, the aim of this study is to determine the spectral region that best discriminates the 3 subtropical mangrove species at the leaf level, between 2 canopy heights, during 2 seasons (rainy and dry), and between 2 physiognomic types (fringe and basin).

\section{MATERIALS AND METHODS}

\section{Study area}

Field work was carried out along the southern part of the coastal lagoon in the Urías system, Sinaloa, Mexico (23 $13^{\circ}-$ $23^{\circ} 11^{\prime} \mathrm{N}, 106^{\circ} 23^{\prime}-106^{\circ} 21^{\prime} \mathrm{W}$ ), during the end of the dry season (May) and the rainy season (October) in 2010 (Fig. 1). Three mangrove species were selected: Laguncularia racemosa
Vog1, el cual utiliza longitudes de onda cercanas al borde del rojo (740 y $720 \mathrm{~nm}$ ). Pastor-Guzman et al. (2015) estimaron el contenido de clorofila en 4 especies de mangle tropical del golfo de México durante la temporada de frentes fríos a partir de 21 índices de vegetación provenientes de datos espectroscópicos (350-2,500 nm). Sus resultados indicaron que es posible estimar el contenido de clorofila usando las longitudes de onda del borde del rojo (705-753 nm) y extrapolar esta estimación a áreas de interés por medio de imágenes de Landsat 8. Heenkenda et al. (2015) estimaron el contenido de clorofila a nivel de cobertura de bosque de mangle en Australia por medio de mediciones en campo y una imagen de alta resolución espacial de WorldView-2. Sus resultados indicaron que es posible estimar el contenido de clorofila a nivel de dosel forestal usando la banda del rojo (630-690 nm), del borde del rojo $(705-740 \mathrm{~nm})$, del infrarrojo cercano $1(770-895 \mathrm{~nm})$ y del infrarrojo cercano $2(860-900 \mathrm{~nm})$. Flores-de-Santiago et al. (2016) estimaron el contenido de pigmentos (chla, chlb, carotenoides totales) con datos espectroscópicos (350-1,000 nm) por medio de correlogramas para 3 especies de mangle subtropical durante 2 temporadas (lluvia y estiaje). Sus resultados indicaron diferencias en las estimaciones del contenido de pigmentos que dependían de la temporada y la especie.

A diferencia de los varios estudios sobre la estimación del contenido de pigmentos fotosintéticos, los estudios sobre la discriminación de especies por medio de datos espectroscópicos son escasos. Por ejemplo, Vaiphasa et al. (2005) analizaron datos espectroscópicos (350-2,500 nm) de 16 especies de mangle tropical en Tailandia usando gráficas de distribución de probabilidad (análisis de varianza [ANDEVA]) y la distancia de Jeffries-Matusita, y sugirieron que las 16 especies de mangle pueden ser clasificadas de acuerdo con 4 regiones espectrales situadas a $720,1,277,1,415$ y $1,644 \mathrm{~nm}$. Wang y Sousa (2009) estudiaron las variaciones espectroscópicas (350-2,500 nm) de 3 especies de mangle tropical en Panamá usando gráficas de distribución de probabilidad (ANDEVA) y un análisis discriminante lineal, e indicaron una separación entre las 3 especies utilizando las longitudes de onda de $780,790,800,1,480,1,530$ y $1,550 \mathrm{~nm}$. Panigrahy et al. (2012) aplicaron gráficas de distribución de probabilidad (ANDEVA) y el análisis de factor con datos espectroscópicos (350-2,500 nm) de 4 especies de mangle tropical en la India, y demostraron una separación entre las 4 especies con datos de la banda del rojo, del infrarrojo cercano y del infrarrojo medio. Zhang et al. (2014) aplicaron el análisis de componentes principales y el análisis discriminante a datos espectroscópicos (350-2,500 nm) de 3 especies de mangle subtropical durante la temporada de estiaje, y sugirieron una separación de especies máxima en las longitudes de onda de $520,560,650,710,760,2,100$ y $2,230 \mathrm{~nm}$.

La gran mayoría de los estudios espectroscópicos se han centrado en analizar especies de mangle en una sola temporada sin tomar en cuenta la distribución vertical de las hojas dentro del dosel forestal. Se sabe que la distribución vertical de pigmentos fotosintéticos varía dependiendo de la 


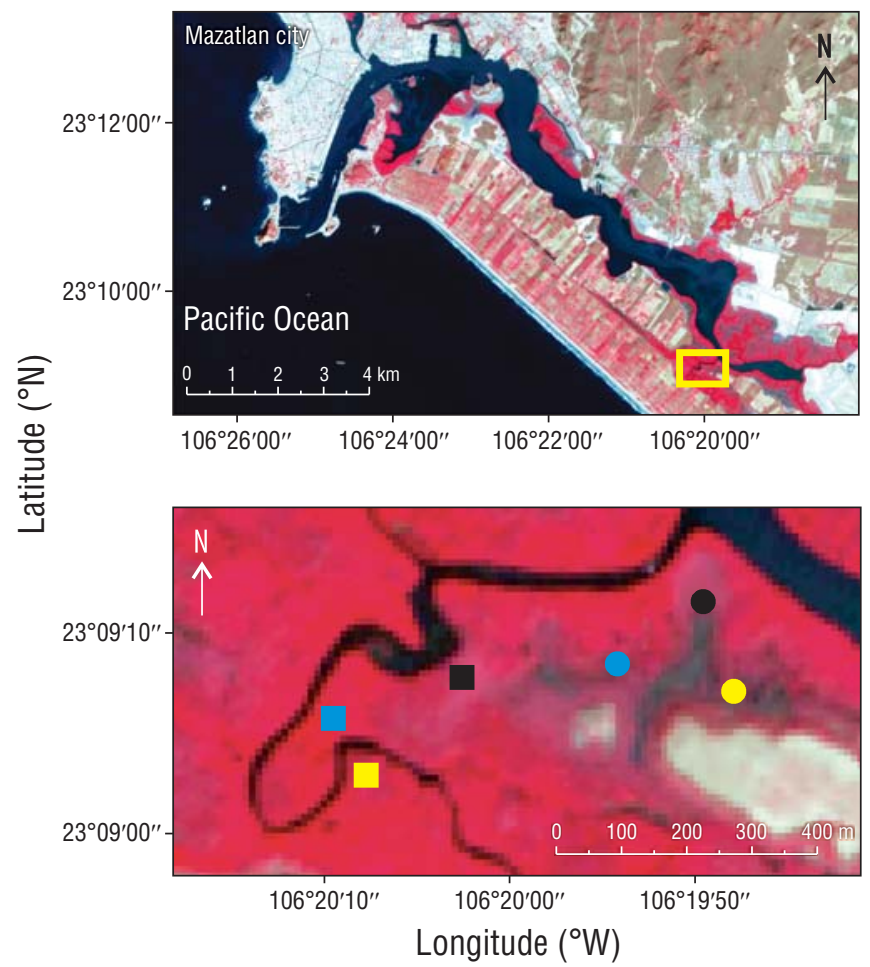

Figure 1. Location of the mangrove forest study area (yellow rectangle) on the southwestern section of the Urías coastal lagoon, Pacific coast of Mexico (enhanced near-infrared, red, and green bands from Sentinel-2; 26 January 2017). Filled circles indicate the sampling locations in the basin and filled squares the sampling locations in the fringe zone. Colors indicate mangrove species: Avicennia germinans (black), Laguncularia racemosa (yellow), and Rhizophora mangle (blue).

Figura 1. Ubicación del área de estudio del manglar (rectángulo amarillo) en la sección suroeste de la laguna costera de Urías, costa mexicana del Pacífico (bandas mejoradas del infrarrojo cercano, rojo y verde del Sentinel-2; 26 de enero de 2017). Los círculos indican los sitios de muestreo en la zona de cuenca y los cuadrados indican los sitios de muestreo en la zona de borde. Los colores indican las especies de mangle: Avicennia germinans (negro), Laguncularia racemosa (amarillo) y Rhizophora mangle (azul).

(white mangrove), Rhizophora mangle (red mangrove), and Avicennia germinans (black mangrove). Evaporation rate in the study area exceeds precipitation rate throughout most of the year (Flores-de-Santiago et al. 2012), gradually increasing the salt concentration between the tidal channel and the elevated part of the coastal lagoon (Villalba-Loera 1986). However, tropical storms and hurricanes during the rainy season (June-September) notably increase precipitation, which increases photosynthetic pigment contents in the mangrove forest (Flores-de-Santiago et al. 2012).

In this subtropical coastal lagoon, where freshwater input is not constant, tides play an important role in the hydroperiod (flood frequency and duration) of the mangrove forest (Monroy-Torres et al. 2015). Consequently, the fringe mangrove community is in a zone where flood frequency is higher temporada del año, la especie y la distribución fisiognómica (Flores-de-Santiago et al. 2012), por lo que suponemos que la intensidad de la señal espectroscópica presenta variabilidad temporal. Por lo tanto, el objetivo de este estudio es determinar la región espectral que mejor discrimine las 3 especies de mangle subtropical a nivel de hoja, entre 2 alturas de dosel, durante 2 temporadas (lluvia y estiaje) y en 2 condiciones fisiognómicas (borde y cuenca).

\section{MATERIALES Y MÉTODOS}

\section{Área de estudio}

El trabajo de campo fue realizado a lo largo de la parte sur de la laguna costera del sistema de Urías, Sinaloa, México $\left(23^{\circ} 13^{\prime}-23^{\circ} 11^{\prime} \mathrm{N}, 106^{\circ} 23^{\prime}-106^{\circ} 21^{\prime} \mathrm{W}\right)$, durante el final de la temporada de estiaje (mayo) y de lluvia (octubre) del año 2010 (Fig. 1). Tres especies de mangle fueron seleccionadas: Laguncularia racemosa (mangle blanco), Rhizophora mangle (mangle rojo) y Avicennia germinans (mangle negro). La tasa de evaporación en el área de estudio excede a la de precipitación durante la mayor parte del año (Flores-de-Santiago et al. 2012), lo que ocasiona un incremento gradual en la concentración de sal entre el canal de mareas y la parte elevada de la laguna costera (Villalba-Loera 1986). Sin embargo, la presencia de tormentas tropicales y huracanes durante la temporada de lluvia (junio a septiembre) ocasiona un incremento notable en la precipitación, la cual ocasiona un aumento en el contenido de pigmentos fotosintéticos en el bosque de mangle (Flores-de-Santiago et al. 2012).

En esta laguna costera subtropical, donde no hay una entrada de agua dulce constante, la marea juega un papel importante en el hidroperiodo (frecuencia y duración de la inundación) del bosque de mangle (Monroy-Torres et al. 2015). Como consecuencia, la comunidad de mangle tipo borde se encuentra en una zona donde la frecuencia de inundación es mayor y la salinidad promedio es de 35 en comparación con la zona donde se ubica la comunidad tipo cuenca, donde la salinidad intersticial promedio es de 80 (Flores-Verdugo et al. 2015, Flores-Verdugo et al. 2018). Por lo tanto, analizamos las 3 especies de mangle en una comunidad tipo borde (saludable) y en una comunidad tipo cuenca (estresado).

\section{Adquisición de datos espectroscópicos}

Para ambas temporadas (lluvia y estiaje), seleccionamos 3 árboles representativos por especie y por condición fisiognómica. De cada árbol, recolectamos 10 hojas aleatorias de la parte superior del dosel arbóreo, bajo la radiación directa del sol, y 10 hojas de la parte inferior del dosel, en sombra permanente. De manera específica, la tercera hoja a partir de la punta de la rama fue cortada para evitar recolectar hojas en senescencia (Biber 2007). Una vez cortadas, todas las muestras fueron almacenadas individualmente en bolsas de 
and average salinity is 35 compared with the zone in which the basin community is found, where average interstitial salinity is 80 (Flores-Verdugo et al. 2015, Flores-Verdugo et al. 2018). Hence, we analyzed the 3 mangrove species in a fringe mangrove community (healthy) and in a basin mangrove community (stressed).

\section{Spectroscopic data acquisition}

For both seasons (rainy and dry), we selected 3 representative trees per species and physiognomic type. From each tree, we collected 10 random leaves from the upper part of the tree canopy, under direct solar radiation, and 10 leaves from the lower part of the canopy, in permanent shade. Specifically, the third leaf on the branch, from the tip down, was collected to avoid taking senescing leaves (Biber 2007). Once cut, all samples were individually stored in plastic bags and placed in a cool box at $4{ }^{\circ} \mathrm{C}$ until spectroscopic measurements in the laboratory. The time between leaf collection and leaf analysis at the laboratory was $3 \mathrm{~h}$. Leaf degradation is considered to be minimal so long as leaves are kept refrigerated and no considerable length of time passes by (Zhang et al. 2012). The spectroscopic reflectance of each leaf was measured with a FieldSpec HandHeld spectroradiometer (ASD, United Kingdom). An average of 10 readings were used for each sample avoiding the central axis with the $\mathrm{RS}^{3}$ program. The instrument wavelength range was $325-1,075 \mathrm{~nm}$ and spectral resolution was $1 \mathrm{~nm}$. However, values under $450 \mathrm{~nm}$ and over 1,000 $\mathrm{nm}$ were eliminated due to noise caused by the instrument. Also, the spectroradiometer was fitted with a probe (Plant Probe) by an optic fiber cable to obtain a constant reading area over each leaf.

\section{Statistical analysis}

Maximum variability zones between the 3 species were analyzed using probability distribution plots of the 550 average reflectance values $(450-1,000 \mathrm{~nm})$ from the upper and lower parts of the tree canopy. This method was chosen for its efficiency when using continuous data, as it eliminates visual interpretation susceptibility in the analysis of reflectance curves (Sokal and Rohlf 2012). In addition, probability distribution plots help eliminate regions along the electromagnetic spectrum where the probability value $(P)$ is higher than 0.01 or 0.05 ( $99 \%$ and $95 \%$ confidence limits, respectively). Briefly, the probability distribution plot provides a first approximation to the discrimination of spectroscopic data. In addition to the probability distribution plots, the first derivative of the electromagnetic spectrum was generated for every species and season. The information provided by the first derivative of continuous reflectance data has proven useful for discriminating vegetation (Cochrane 2000). In essence, the first derivative indicates if a function is increasing or decreasing and the rate of change. In graphical terms, the function reflects the slope of a tangent line to a base plástico y colocadas en una hielera a $4{ }^{\circ} \mathrm{C}$ hasta realizar las medidas espectroscópicas en el laboratorio. El tiempo entre la recolecta de hojas y el análisis en el laboratorio fue de $3 \mathrm{~h}$. Se estima que la degradación de las hojas es mínima siempre y cuando las muestras estén en refrigeración y no transcurra un tiempo considerable (Zhang et al. 2012). Para cada hoja, la reflectancia espectroscópica fue medida por medio de un espectroradiómetro FieldSpec HandHeld (ASD, Reino Unido). Se utilizó un promedio de 10 lecturas para cada muestra evitando el eje central con el programa $\mathrm{RS}^{3}$. El instrumento tiene un intervalo espectral de 325-1,075 nm y una resolución de $1 \mathrm{~nm}$. Sin embargo, los valores por debajo de $450 \mathrm{~nm}$ y por encima de $1,000 \mathrm{~nm}$ fueron eliminados debido a ruido ocasionado por el instrumento. Asimismo, una sonda (Plant Probe) fue adicionada al espectroradiómetro por medio de un cable de fibra óptica para obtener un área de lectura constante sobre cada hoja.

\section{Análisis estadístico}

Se analizaron las zonas de variabilidad máxima entre las 3 especies por medio de gráficas de distribución de probabilidad a partir de los 550 valores promedio de reflectancia $(450-1,000 \mathrm{~nm})$ de la parte superior y la parte inferior del dosel arbóreo. Este método fue elegido debido a su eficacia en datos continuos al eliminar la susceptibilidad de la interpretación visual al momento de analizar curvas de reflectancia (Sokal y Rohlf 2012). Además, las gráficas de distribución de probabilidad ayudan a eliminar regiones a lo largo del espectro electromagnético donde el valor de probabilidad $(P)$ es mayor que 0.01 ó 0.05 (límites de confianza del 99\% y $95 \%$, respectivamente). En general, el diagrama de distribución de probabilidad provee una primera aproximación a la discriminación de datos espectroscópicos. Adicional a las gráficas de distribución de probabilidad, se generó la primera derivada del espectro electromagnético para todas las especies y temporadas. La información provista por la primera derivada de datos continuos de reflectancia ha mostrado ser útil para la discriminación de vegetación (Cochrane 2000). En esencia, la primera derivada nos indica si una función tiende a incrementar o a disminuir y su magnitud al cambio. En términos gráficos, la función refleja la pendiente de una línea tangente a partir de una línea base (cero). Mientras más se aleja la función de la línea base, mayor es la variabilidad en la muestra.

Con base en las gráficas de distribución de probabilidad y primera derivada, se seleccionaron aquellos intervalos del espectro electromagnético donde se presentaron variabilidades mayores entre las especies. Dichos intervalos fueron evaluados con el análisis discriminante canónico (ADC) para comprobar la separación entre las 3 especies de mangle. El ADC es una técnica de reducción dimensional equivalente al análisis de correlación canónico, el cual es usado para determinar relaciones entre las variables cuantificadas dentro de un espacio discriminante. En particular, el ADC 
line on the graph (zero). The further the function is from the base line, the greater the variability of the sample.

Using the probability and first-derivative plots, we selected the wavelengths that showed the highest variabilities between species. These intervals were assessed with a canonical discriminant analysis (CDA) to verify the separation between the 3 mangrove species. The CDA is a dimension-reduction technique equivalent to the canonical correlation analysis, which is used to determine relationships between quantified variables in a discriminant space. Specifically, the CDA derives linear combinations from the original variables in the first 2 principal components, which explain much of the total variance (Sokal and Rohlf 2012). We also selected the wavelengths Wang and Sousa (2009) suggested for the discrimination of the same 3 mangrove species and the wavelengths Zhang et al. (2014) analyzed to discriminate the red and black mangroves. All calculations and figures were generated in Matlab.

\section{ReSUlTS}

Basin mangrove samples exhibited higher reflectance variabilities along the electromagnetic spectrum compared with the fringe mangrove samples (Fig. 2). From the fringe mangrove samples, the white and black mangroves exhibited the lowest variabilities in the visible region of the electromagnetic spectrum. For the rest of the classes, high-variability regions were found between the green and red bands (500-680 nm) and along the near-infrared band $(750-1,000 \mathrm{~nm})$. With respect to the probability distribution plots for the dry season, a unique pattern in the mangrove classes was not found because variability was high (Fig. 3). Only the comparison between $L$. racemosa and $R$. mangle exhibited regions where there were no significant differences $(P>0.05)$ between leaves from the upper and lower parts of the forest canopy. However, the regions were not always present in all physiognomic types and fluctuated between the red-edge and near-infrared regions. Leaf samples taken during the rainy season showed a more diverse pattern (Fig. 4). Notably, basin mangrove samples exhibited regions where there were no significant differences $(P>0.05)$ along the blue $(450-500 \mathrm{~nm})$, yellow-to-orange $(570-610 \mathrm{~nm})$, red-edge $(700-720 \mathrm{~nm})$, and near-infrared bands. By contrast, fringe mangrove samples taken during the rainy season exhibited zones of minimum variability between $L$. racemosa and $R$. mangle at the start of the near-infrared region $(740 \mathrm{~nm})$. Note that the green $(500-570 \mathrm{~nm})$ and near-infrared $(780-1,000 \mathrm{~nm})$ regions showed significant differences $(P<0.01)$ between all classes and physiognomic types.

In general, first-derivative plots for the dry (Fig. 5) and rainy (Fig. 6) seasons did not show constant trends. However, areas with no apparent changes corresponded to wavelengths under $540 \mathrm{~nm}, 600-700 \mathrm{~nm}$, and 740-1,000 nm. On the contrary, trends with notable changes were present at $540-560 \mathrm{~nm}$ and $700-720 \mathrm{~nm}$. On the basis of our previous results, we deriva combinaciones lineales de las variables originales en los primeros 2 componentes principales, los cuales explican la mayor parte de la variabilidad total (Sokal y Rohlf 2012). Además, se seleccionaron las longitudes de onda sugeridas por Wang y Sousa (2009) para la discriminación de las mismas 3 especies de mangle y las longitudes de onda analizadas por Zhang et al. (2014) para la discriminación del mangle rojo y del mangle negro. Todos los cálculos y figuras fueron generados en Matlab.

\section{RESUltados}

Las muestras de mangle tipo cuenca presentaron variabilidades mayores en la reflectancia a lo largo del espectro electromagnético comparadas con las muestras de mangle tipo borde (Fig. 2). Dentro de las muestras de mangle tipo borde, el mangle blanco y el negro presentaron las variabilidades menores en la región visible del espectro electromagnético. Para las clases restantes, las regiones de variabilidad mayor fueron localizadas en las bandas del verde al rojo $(500-680 \mathrm{~nm})$ y a lo largo del infrarrojo cercano $(750-1,000 \mathrm{~nm})$. Respecto a las gráficas de distribución de probabilidad para la temporada de estiaje, no se encontró un patrón único en las clases de mangle debido a que la variabilidad fue muy alta (Fig. 3). Solo la comparación entre L. racemosa y $R$. mangle presentó regiones donde no hubieron diferencias significativas $(P>0.05)$ entre hojas de la parte superior y las de la parte inferior del dosel forestal. Sin embargo, las regiones no siempre se presentaron en todas las condiciones fisiognómicas y fluctuaron entre el borde del rojo y el infrarrojo cercano. Un patrón más diverso se presentó en las muestras de hojas durante la temporada de lluvia (Fig. 4). En particular, las muestras de mangle tipo cuenca presentaron regiones donde no hubieron diferencias significativas $(P>0.05)$ a lo largo de la banda del azul (450-500 nm), del amarillo a naranja (570$610 \mathrm{~nm})$, del borde del rojo $(700-720 \mathrm{~nm})$ y del infrarrojo cercano. Por el contrario, las muestras de mangle tipo borde durante la temporada de lluvia presentaron zonas de variabilidad mínima entre L. racemosa y $R$. mangle al inicio del infrarrojo cercano $(740 \mathrm{~nm})$. Cabe destacar que las regiones del verde (500-570 nm) e infrarrojo cercano (780-1,000 nm) presentaron diferencias significativas $(P<0.01)$ entre todas las clases y condiciones.

En general, las gráficas de la primera derivada para las temporadas de estiaje (Fig. 5) y lluvia (Fig. 6) no presentaron tendencias constantes. Sin embargo, las zonas donde no se presentaron cambios aparentes correspondieron a longitudes de onda menores que $540 \mathrm{~nm}$, de 600 a $700 \mathrm{~nm}$ y de 740 a $1,000 \mathrm{~nm}$. Por el contrario, tendencias con un cambio notable se presentaron de 540 a $560 \mathrm{~nm}$ y de 700 a $720 \mathrm{~nm}$. Con base en los resultados mencionados con anterioridad, se seleccionaron las regiones del verde $(540-560 \mathrm{~nm}) \mathrm{y}$ del borde del rojo $(700-720 \mathrm{~nm})$ para el ADC.

El ADC mostró una discriminación exitosa entre las especies de mangle al momento de utilizar las longitudes de onda 

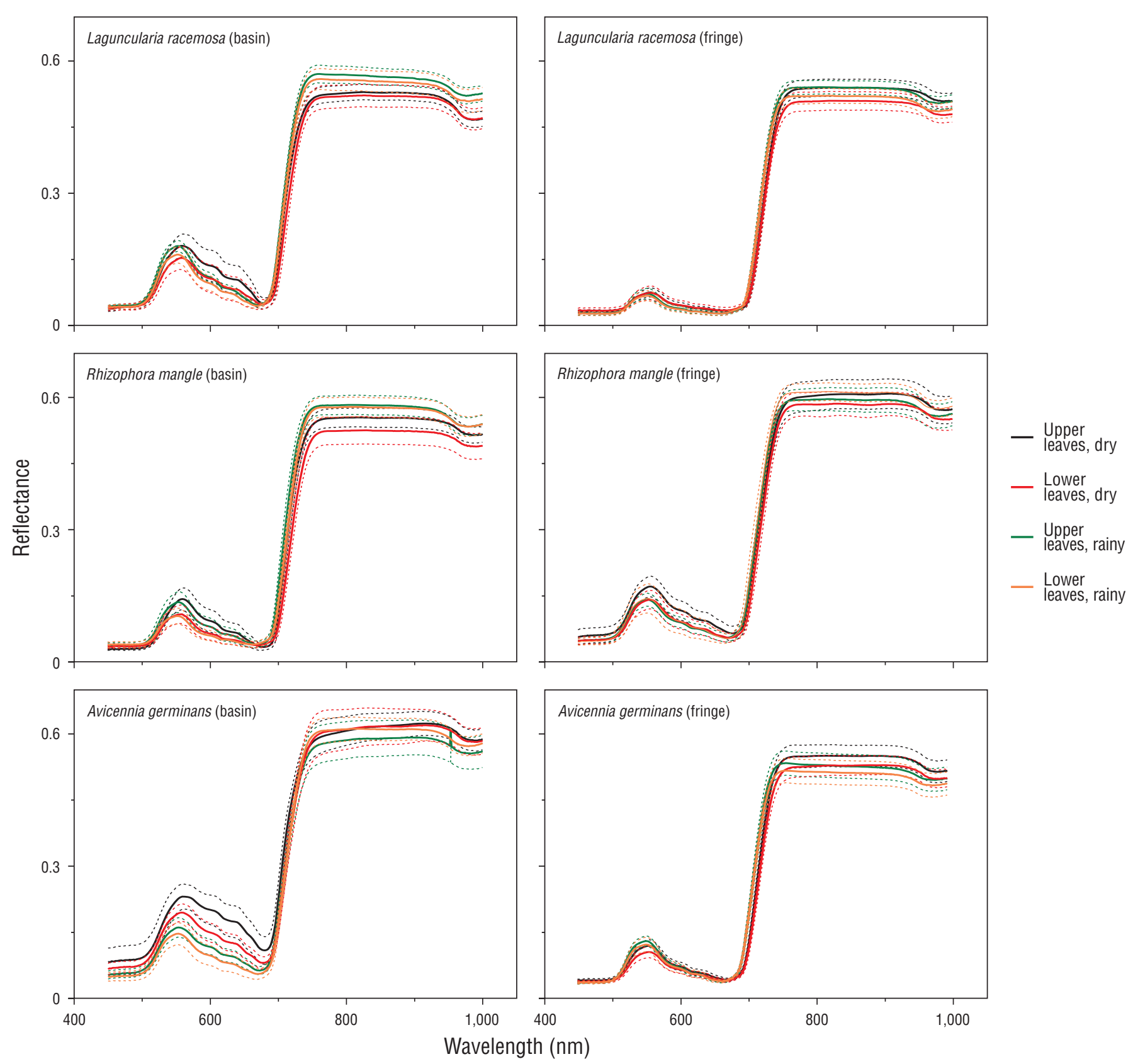

Figure 2. Average reflectance $(n=30$, solid line) and first standard deviation (dashed line) for leaves of 3 mangrove species in basin and fringe forests.

Figura 2. Reflectancia promedio ( $n=30$, línea continua) y primera desviación estándar (línea discontinua) para hojas de 3 especies de mangle tipo cuenca y tipo borde.

selected the green $(540-560 \mathrm{~nm})$ and red-edge $(700-720 \mathrm{~nm})$ regions for the CDA.

The CDA showed successful discrimination between mangrove species when the green and red-edge wavelengths were used (Fig. 7). Species in the basin mangrove forest showed notable separation between samples from upper and lower parts of the forest canopy during the dry season. During the rainy season, the 3 mangrove species could be separated, but no significant differences were found between both parts del verde y del borde del rojo (Fig. 7). En particular, las especies de mangle tipo cuenca presentaron una separación notable entre las muestras de la parte superior y las de la parte inferior del dosel forestal durante la temporada de estiaje. Durante la temporada de lluvia, fue posible separar las 3 especies de mangle, pero no hubieron diferencias significativas entre las partes del dosel. Este último patrón se observó para las muestras de mangle tipo borde durante ambas temporadas. No es posible separar especies y condiciones fisiognómicas 
of the canopy. This last pattern was observed for the fringe mangrove samples during both seasons. It was not possible to separate species and physiognomic types using the wavelengths suggested by Wang and Sousa (2009) for the same 3 mangrove species (Fig. 8). Only the combination of wavelengths suggested by Zhang et al. (2014) can discriminate basin and fringe mangrove species during the rainy season (Fig. 9). However, Zhang et al. (2014) did not include spectral data on the white mangrove, and low discrimination between species and physiognomic types was thus to be expected.

\section{Discussion}

Discrimination of mangrove species at the leaf level using spectroscopic data is the first step to obtaining an optimal classification of a mangrove forest in a dynamic environment. The results of our analysis show that the distribution of leaves in forest canopies plays an important role in the spectroscopic variability in the types of mangroves, particularly in stressed mangrove forests. This could be a fundamental factor when classifying a mangrove forest using satellite imagery, but it depends on the season during which the images are obtained. Another factor that must be considered is physiognomic classification, since the same species exhibited spectroscopic differences according to physiognomic types.

Within the current techniques for selecting optimal wavelengths from spectroscopic data, the use of probability distribution plots (ANOVA) has been suggested as an efficient method to limit the number of data when classifying mangroves (Wang and Sousa 2009, Panigrahy et al. 2012). However, ANOVA diagrams did not distinguish the zones where the 3 species presented spectroscopic similarities (data not shown). For this reason, we had to use a more thorough method when plotting probability distributions, which included pairwise comparisons between species (see Figs. 3, 4). We expected our data to show higher variability compared with that reported in previous studies, such as that by Wang and Sousa (2009), in which different mangrove species in tropical environments were analyzed and no apparent differences between samples from the upper and lower parts of the forest canopy were found. Changes in the composition of photosynthetic pigments with respect to the position of leaves in the forest canopy have been reported (Flores-deSantiago et al. 2012), and in our study, the position (upper or lower) of leaves largely influenced the determination of spectroscopic variability in the basin mangrove samples.

Although we obtained detailed results with the probability distribution plots by pairs of species, it was necessary to include the first-derivative analysis in order to choose the optimal wavelengths. As a result, wavelengths from the green $(540-560 \mathrm{~nm})$ and red-edge $(700-720 \mathrm{~nm})$ regions showed effective discrimination between mangrove species. The significance of the green and red-edge wavelengths in the spectroscopic analysis of tropical vegetation is not a novel finding. For example, previous studies have achieved al momento de utilizar las longitudes de onda sugeridas por Wang y Sousa (2009) para las mismas 3 especies de mangle (Fig. 8). Solo la combinación de longitudes de onda sugeridas por Zhang et al. (2014) puede llegar a discriminar las especies de mangle tipo cuenca y de mangle tipo borde durante la temporada de lluvia (Fig. 9). Sin embargo, Zhang et al. (2014) no incluyeron datos espectrales de mangle blanco, por lo que era de esperarse una discriminación baja entre especies y condiciones.

\section{Discusión}

La discriminación de especies de mangle a nivel de hoja por medio de datos espectroscópicos es el primer paso para obtener una clasificación óptima de un bosque de mangle en un ambiente dinámico. Los resultados de nuestro análisis muestran como la distribución de las hojas en el dosel forestal juega un papel importante en la variabilidad espectroscópica en las clases de mangle, en particular el mangle estresado. Este factor pudiera ser fundamental al momento de clasificar un bosque de mangle por medio de imágenes de satélite, pero depende de la temporada en la que estas se adquieran. Otra cuestión que debe considerarse es la clasificación fisiognómica, ya que las mismas especies presentaron diferencias espectroscópicas según su condición fisiognómica.

Dentro de las técnicas que existen para seleccionar longitudes de onda óptimas provenientes de datos espectroscópicos, el uso de diagramas de distribución de probabilidad (ANDEVA) ha sido sugerido como un método eficaz para limitar el número de datos al momento de clasificar el mangle (Wang y Sousa 2009, Panigrahy et al. 2012). Sin embargo, los diagramas del ANDEVA no mostraron distinción de zonas donde las 3 especies presentaron similitudes espectroscópicas (datos no presentados). Por tal motivo, tuvimos que utilizar un método más minucioso al momento de graficar las distribuciones de probabilidad, las cuales incluyeron la comparación por pares de especies (ver Figs. 3, 4). Era de esperarse que nuestros datos presentaran una variabilidad mayor comparada con la reportada en estudios previos como, por ejemplo, el de Wang y Sousa (2009), en el cual diferentes especies de mangle en ambientes tropicales fueron analizadas y no se encontró una aparente diferencia entre las muestras de la parte superior y las de la parte inferior del dosel forestal. Se han encontrado cambios en la composición de pigmentos fotosintéticos respecto a la localización de las hojas en el dosel forestal (Flores-de-Santiago et al. 2012), la cual influyó en gran medida al momento de determinar la variabilidad espectroscópica de nuestras muestras en condición de cuenca.

A pesar de obtener resultados detallados con las gráficas de distribución de probabilidad por pares de especies, fue necesario adicionar el análisis de primera derivada para lograr seleccionar longitudes de onda óptimas. Como consecuencia, las longitudes de onda de las regiones del verde (540-560 nm) y borde del rojo (700-720 nm) mostraron una discriminación efectiva entre las especies de mangle. La importancia de 


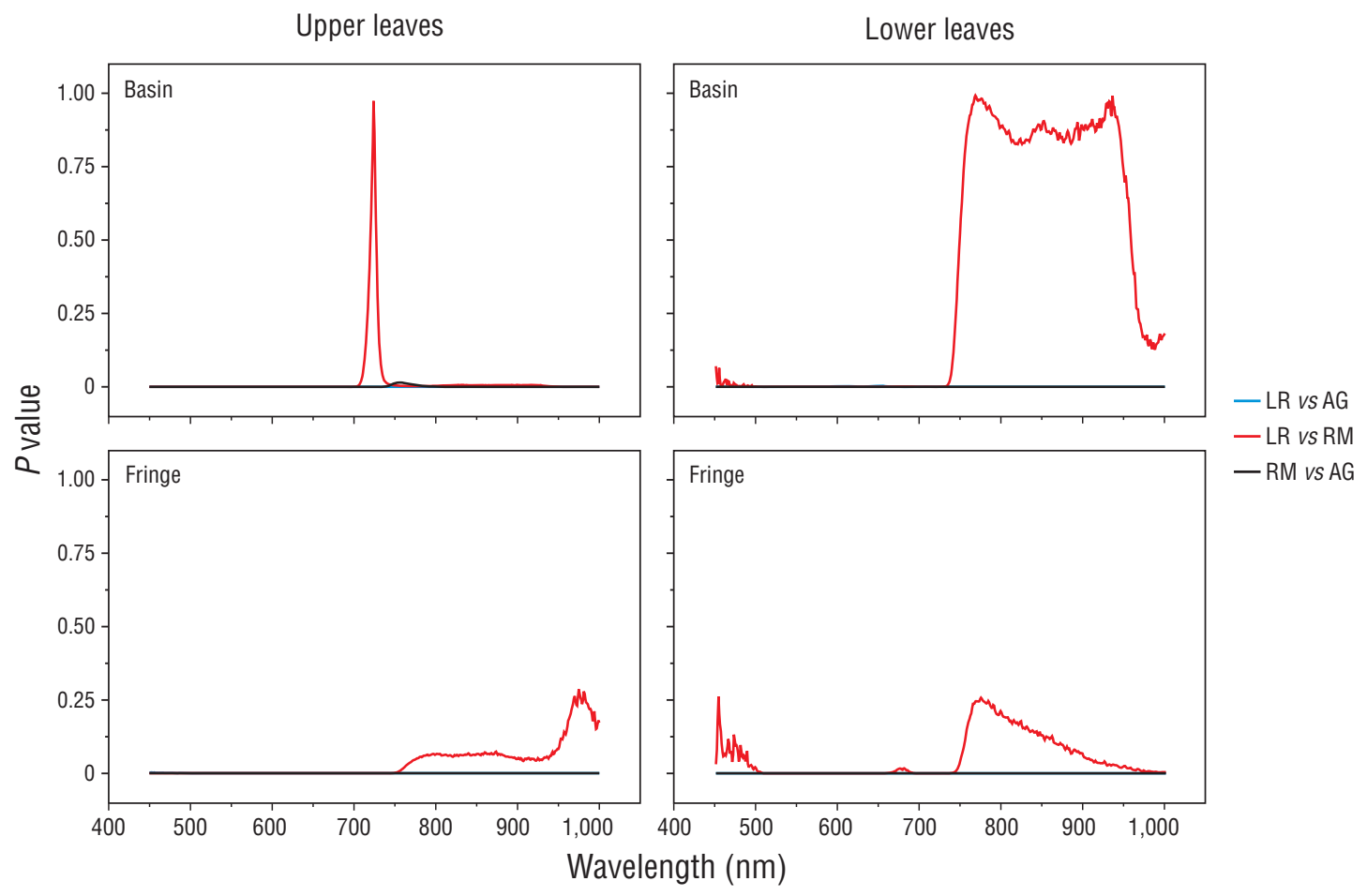

Figure 3. Probability $(P)$ plots of leaf spectral data for Laguncularia racemosa (LR), Rhizophora mangle (RM), and Avicennia germinans (AG) during the dry season.

Figura 3. Gráficas de probabilidad $(P)$ de los datos espectrales de hojas de Laguncularia racemosa (LR), Rhizophora mangle (RM) y Avicennia germinans (AG) durante la temporada de estiaje.

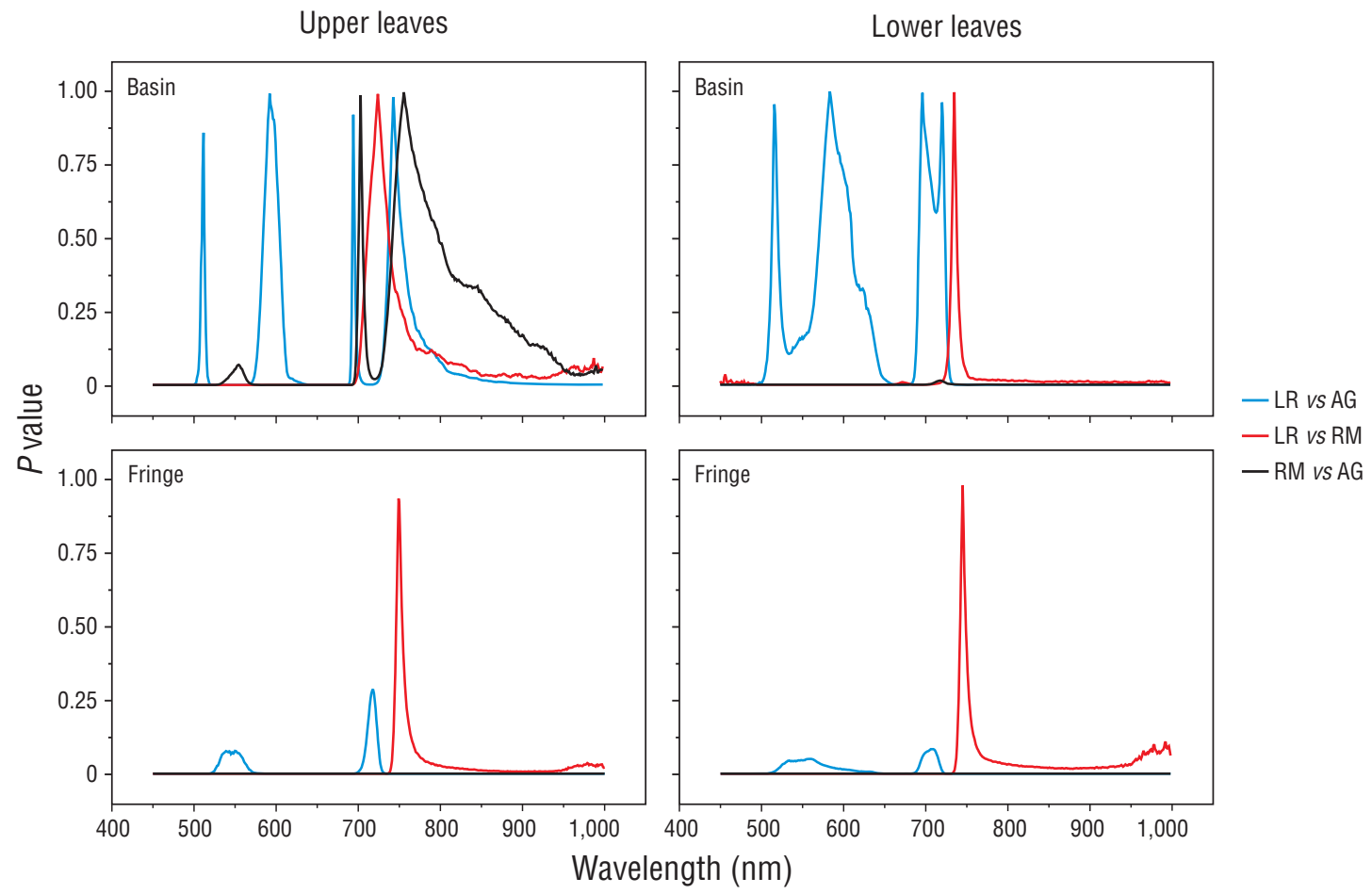

Figure 4. Probability $(P)$ plots of leaf spectral data for Laguncularia racemosa (LR), Rhizophora mangle (RM), and Avicennia germinans (AG) during the rainy season.

Figura 4. Gráficas de probabilidad $(P)$ de los datos espectrales de hojas de Laguncularia racemosa (LR), Rhizophora mangle (RM) y Avicennia germinans (AG) durante la temporada de lluvia. 


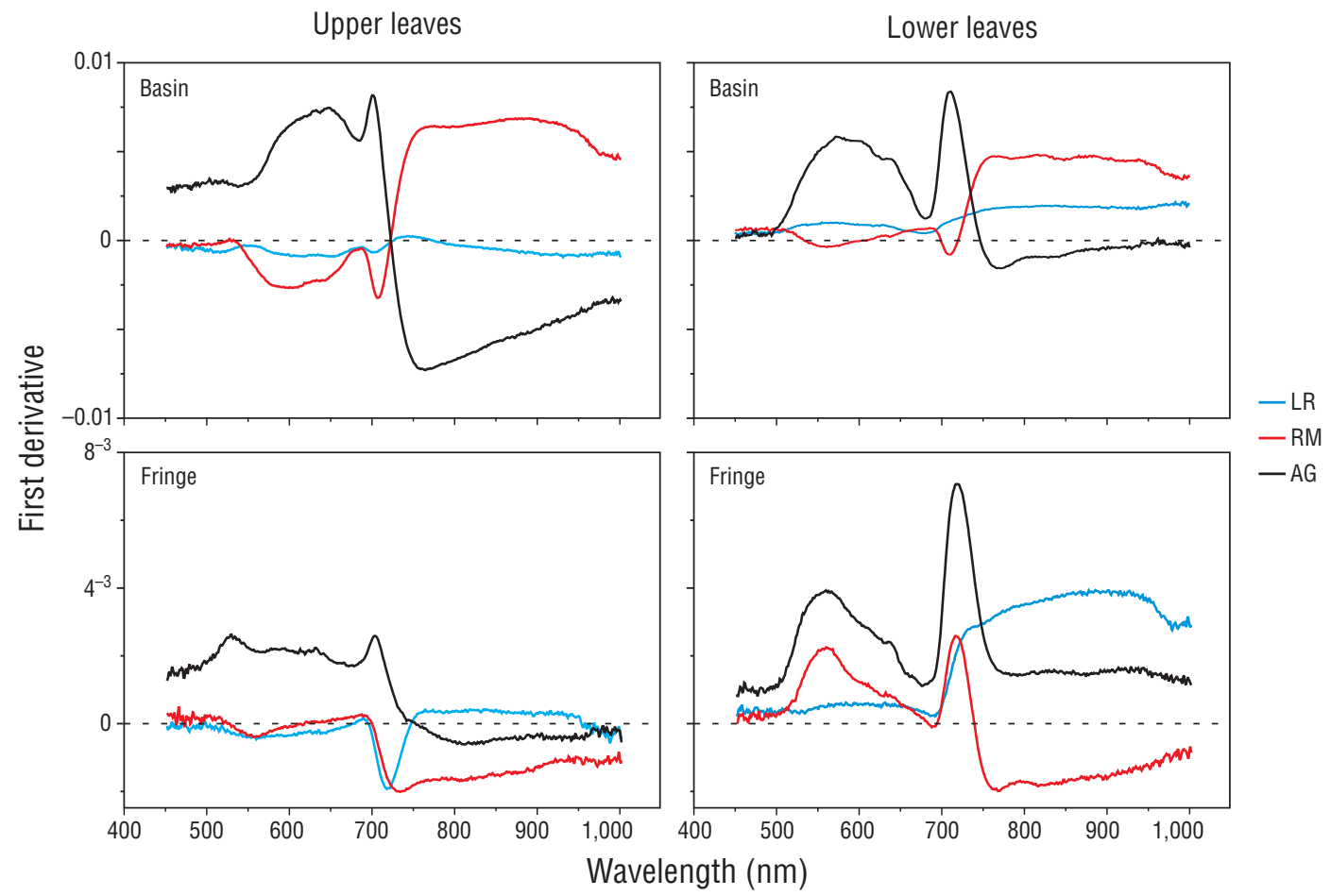

Figure 5. First-derivative plots of leaf spectral data for Laguncularia racemosa (LR), Rhizophora mangle (RM), and Avicennia germinans (AG) during the dry season.

Figura 5. Gráficas de la primera derivada de los datos espectrales de hojas de Laguncularia racemosa (LR), Rhizophora mangle (RM) y Avicennia germinans (AG) durante la temporada de estiaje.

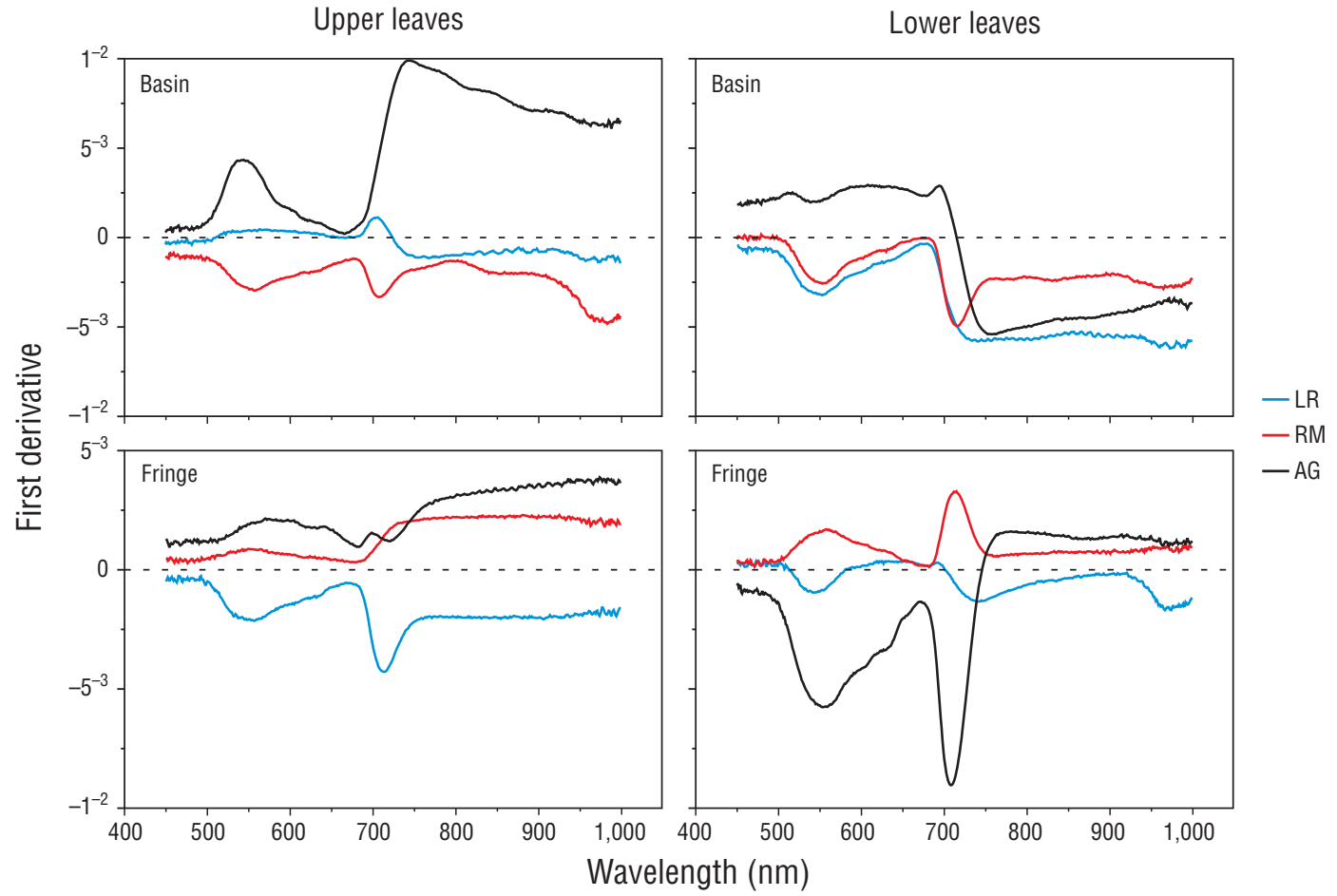

Figure 6. First-derivative plots of leaf spectral data for Laguncularia racemosa (LR), Rhizophora mangle (RM), and Avicennia germinans (AG) during the rainy season.

Figura 6. Gráficas de la primera derivada de los datos espectrales de hojas de Laguncularia racemosa (LR), Rhizophora mangle (RM) y Avicennia germinans (AG) durante la temporada de lluvia. 


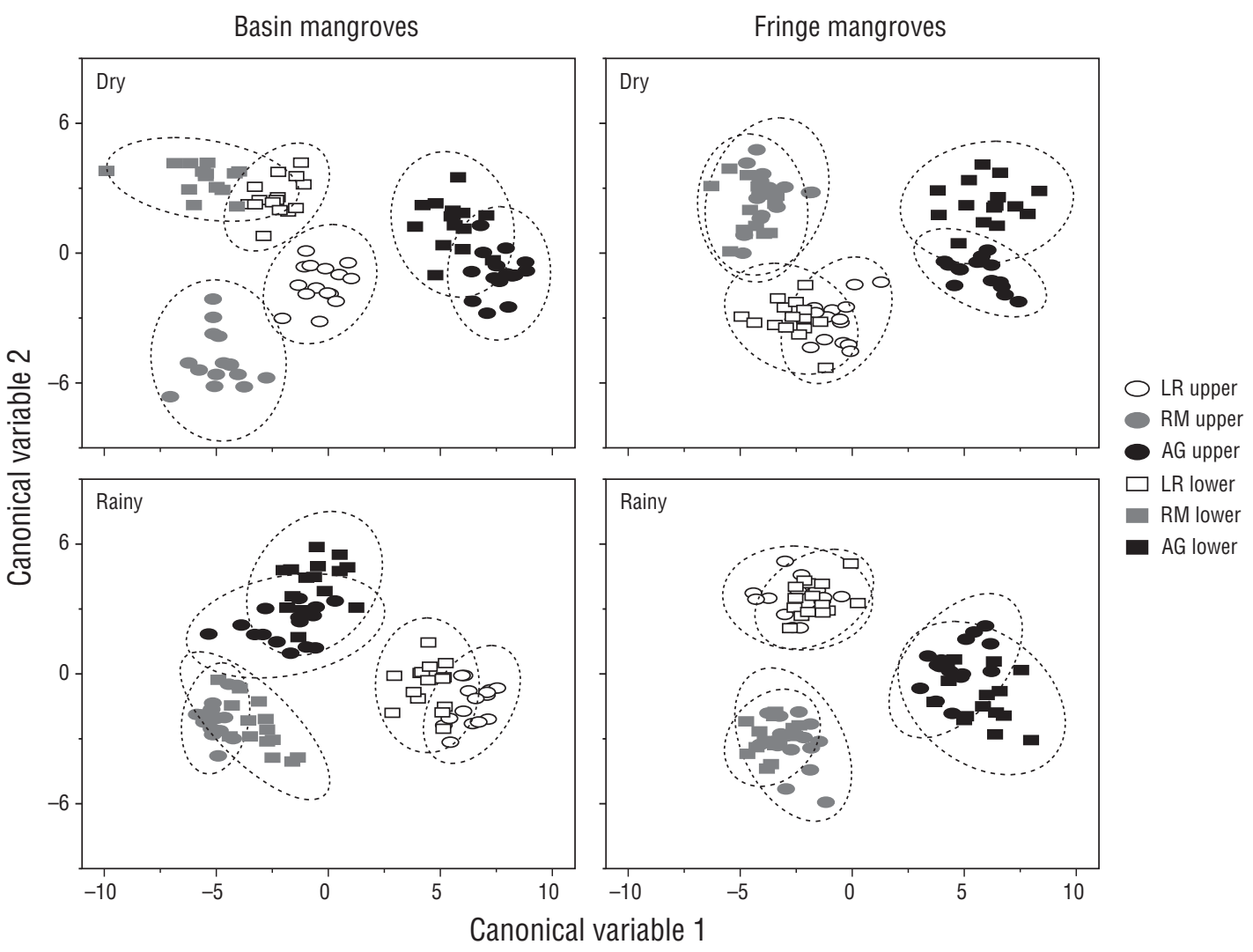

Figure 7. Canonical discriminant analysis combining wavelengths from the 540-560 nm and 700-720 nm bands. Dashed lines represent the 95\% confidence interval. Laguncularia racemosa (LR), Rhizophora mangle (RM), and Avicennia germinans (AG).

Figura 7. Análisis discriminante canónico combinando las longitudes de onda de las bandas de 540-560 nm y 700-720 nm. Las líneas de trazo representan el intervalo de confianza del 95\%. Laguncularia racemosa (LR), Rhizophora mangle (RM) y Avicennia germinans (AG).

effective discrimination when using data with wavelengths around 550 and $745 \mathrm{~nm}$ for several plant species (Gitelson et al. 1996, Lichtenthaler et al. 1996). However, the differences found between physiognomic types and the analyzed seasons, together with the high variability in the spectroscopic response of each mangrove species, suggest that the 3 species respond differently to the aforementioned regions of the electromagnetic spectrum depending on vegetation health.

Most of the previous studies on the classification of mangrove forests have used remote sensing data from conventional platforms (e.g., Landsat, SPOT), which collect information from the visible (blue, green, red) and near-infrared wavebands (Valderrama-Landeros et al. 2018). Traditional vegetation indices (e.g., normalized difference vegetation index, simple ratio) are generated using these wavebands, and these indices have been used to discriminate mangrove species to a certain degree (Kuenzer et al. 2011). Unfortunately, these sensors show limitations in the quantification of photosynthetic pigments (Flores-de-Santiago et al. 2016) and, as a result, in the efficient discrimination of species and physiognomic types because they cannot collect information from the red-edge waveband. In the future, satellite images including data from the red-edge waveband (e.g., Sentinel, RapidEye, las longitudes de onda del verde y borde del rojo no es una cualidad novedosa para el análisis espectroscópico de vegetación tropical. Por ejemplo, estudios previos han logrado una discriminación efectiva al utilizar datos de longitudes de onda de alrededor de 550 y $745 \mathrm{~nm}$ para varias especies de plantas (Gitelson et al. 1996, Lichtenthaler et al. 1996). Sin embargo, las diferencias encontradas entre las condiciones fisiognómicas y las temporadas analizadas, ligadas a la variabilidad elevada en la respuesta espectroscópica de cada una de las especies de mangle, sugieren que las 3 especies responden de manera diferente a dichas regiones del espectro electromagnético dependiendo de su estado de salud.

La mayoría de los estudios previos sobre la clasificación de bosques de mangle se basan en datos de sensores remotos provenientes de plataformas convencionales (e.g., Landsat, SPOT), las cuales obtienen información de las bandas del visible (azul, verde, rojo) y del infrarrojo cercano (Valderrama-Landeros et al. 2018). A partir de estas bandas, se generan índices de vegetación tradicionales (e.g., índice de vegetación de diferencia normalizada, relación simple), los cuales han sido utilizados para discriminar especies de mangle hasta cierto grado (Kuenzer et al. 2011). Lamentablemente, estos sensores remotos se ven limitados en la cuantificación de 
WorldView) and images from remotely piloted aircraft systems (RPAS) could be used to determine photosynthetic pigments and to discriminate mangrove species at the forest canopy level in a more precise manner. However, although our discrimination of mangrove species at the leaf level was high, classification of mangrove species at the forest level using satellite images and RPAS may vary depending on soil reflectance and leaf angle.

Our results were not similar to those reported by Wang and Sousa (2009), who concluded that near-infrared wavelengths were optimal for the separation of the same 3 mangrove species. This discrepancy could be due to differences in the environments in which the mangrove species grew. Specifically, the 3 mangrove species studied by Wang and Sousa (2009) grew in a tropical climate, where there were less stress factors compared with the stress factors under which our mangroves grew. In addition, these authors indicated that there were no differences between leaves from the upper and lower parts of the forest canopy. This result is similar to what we found with our samples from mangroves growing along the tidal channel where stress pigmentos fotosintéticos (Flores-de-Santiago et al. 2016) y, como consecuencia, en la discriminación eficiente de especies y condiciones fisiognómicas debido a que no pueden obtener información del borde del rojo. Es de esperarse que, en un futuro, las imágenes de satélite que incluyan datos provenientes del borde del rojo (e.g., Sentinel, RapidEye, WorldView) e imágenes de sistemas de aeronave pilotada a distancia (RPAS, por sus siglas en inglés) pudieran llegar a ser usadas para determinar pigmentos fotosintéticos y discriminar especies de mangle a nivel de dosel forestal de forma más precisa. Sin embargo, aunque nuestra discriminación de especies de mangle fue elevada a nivel de hoja, la clasificación de especies de mangle a nivel de cobertura con imágenes de satélite y RPAS puede variar dependiendo de la reflectancia del suelo y del ángulo de las hojas.

Nuestros resultados no fueron similares a los reportados por Wang y Sousa (2009), quienes concluyeron que las longitudes de onda del infrarrojo cercano son óptimas para separar las mismas 3 especies de mangle. Quizá esta discrepancia se debe a una diferencia en el ambiente al cual estaban sometidos los mangles. En particular, las 3 especies de mangle estudiadas

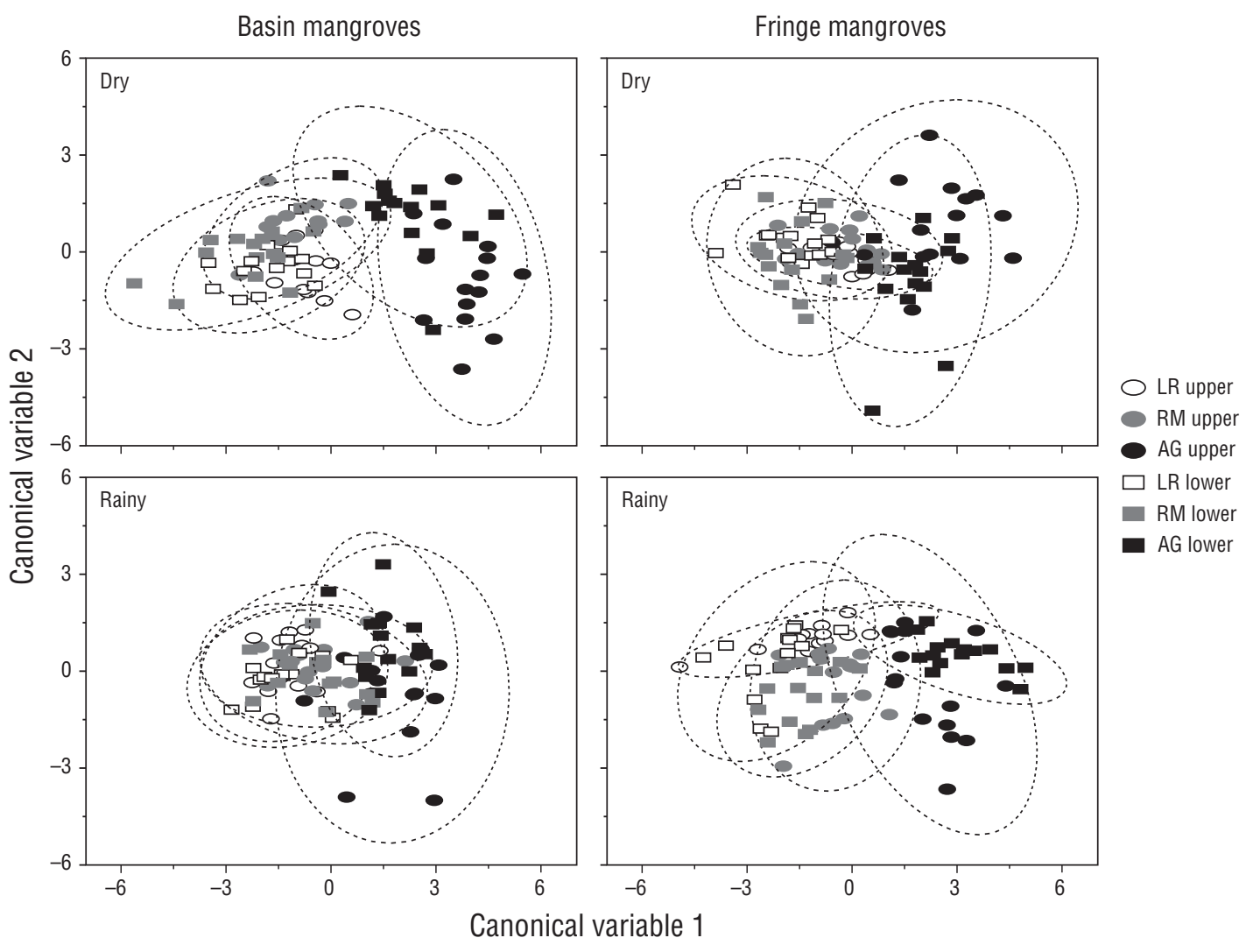

Figure 8. Canonical discriminant analysis combining the wavelengths suggested by Wang and Sousa (2009) (780, 790, and 800 nm). Dashed lines represent the 95\% confidence interval. Laguncularia racemosa (LR), Rhizophora mangle (RM), and Avicennia germinans (AG).

Figura 8. Análisis discriminante canónico en el cual se combinan las longitudes de onda sugeridas por Wang y Sousa (2009) (780, 790 y $800 \mathrm{~nm}$ ). Las líneas discontinuas representan el intervalo de confianza del 95\%. Laguncularia racemosa (LR), Rhizophora mangle (RM) y Avicennia germinans (AG). 


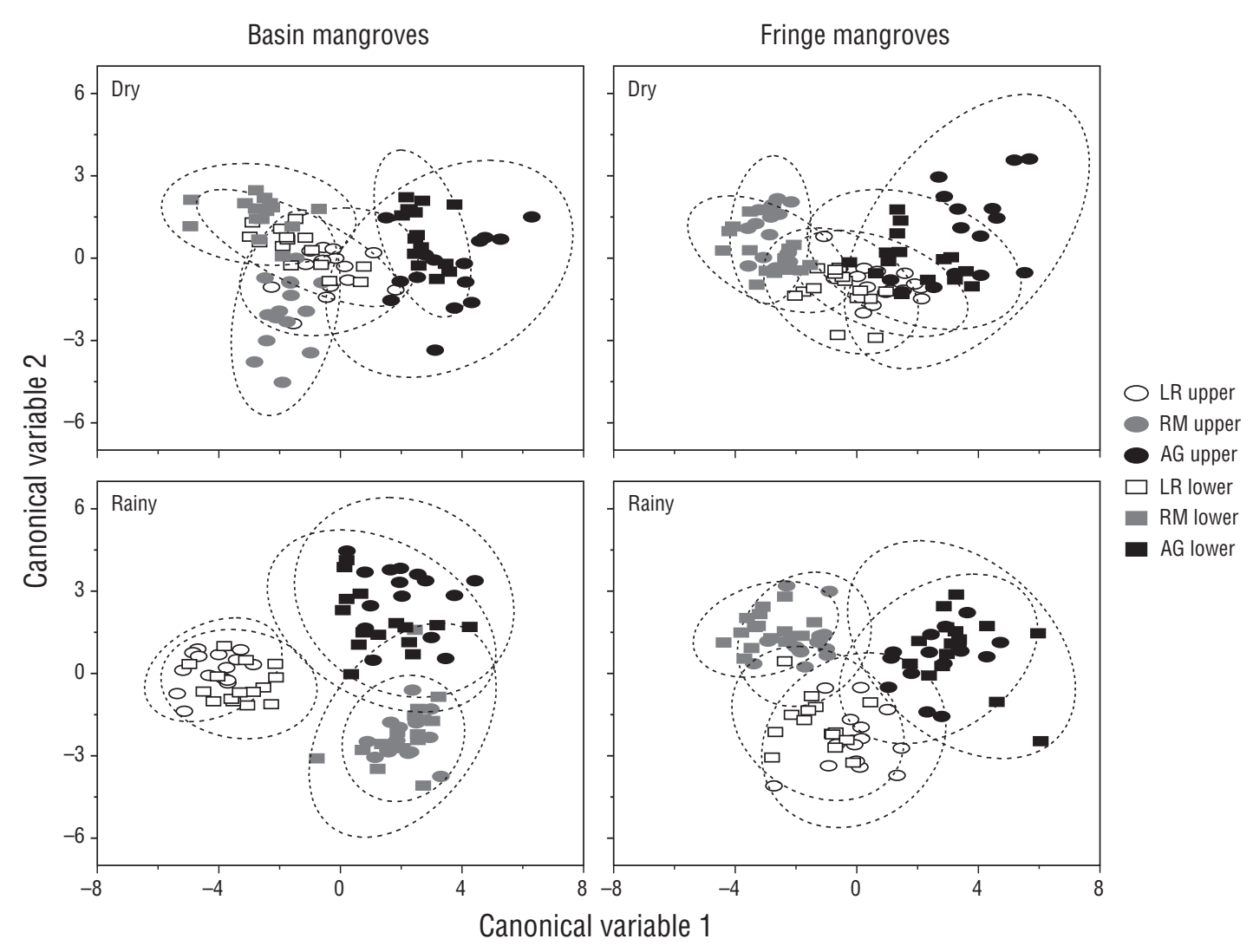

Figure 9. Canonical discriminant analysis combining the wavelengths suggested by Zhang et al. (2014) (520, 560, 650, 710, and 760 nm). Dashed lines represent the $95 \%$ confidence interval. Laguncularia racemosa (LR), Rhizophora mangle (RM), and Avicennia germinans (AG).

Figura 9. Análisis discriminante canónico en el cual se combinan las longitudes de onda sugeridas por Zhang et al. (2014) (520, 560, 710 y 760). Las líneas discontinuas representan el intervalo de confianza del 95\%. Laguncularia racemosa (LR), Rhizophora mangle (RM) y Avicennia germinans (AG).

factors lessened: spectroscopic data did not show differences between the 2 parts of the canopy. Unlike the lack of similarities with the results reported by Wang and Sousa (2009), our results are similar to those reported by Zhang et al. (2014), who found differences between red and black mangroves at specific wavelengths in the green (520 and $560 \mathrm{~nm})$ and red-edge $(710 \mathrm{~nm})$ regions. However, there is a notable difference between our CDA results and those obtained by Zhang et al. (2014), since these authors did not include white mangrove samples and analyzed only one season.

We think that including the green region, together with the red-edge region, could be of great significance for the optimal classification of mangrove forests in subtropical environments where environmental conditions are unfavorable. The red-edge region has been categorized as a fundamental zone for the prediction of photosynthetic pigments in mangrove leaves (Zhang et al. 2012, Flores-de-Santiago et al. 2016) and for the discrimination of mangrove forests in southeast Asia (Koedsin and Vaiphasa 2013). In addition, basin mangroves in the Urías system show a clear seasonal pattern with respect to photosynthetic pigment contents (Flores-de-Santiago et al. por Wang y Sousa (2009) provenían de un clima tropical, en el cual los factores estresantes fueron menores comparados con los factores estresantes bajo los cuales se encontraban nuestros mangles. Además, los mismos autores indicaron que no hubo una diferencia entre las hojas de la parte superior y las de la parte inferior del dosel forestal. Dicho resultado es similar a lo que encontramos con las muestras de los mangles localizados al borde del canal de mareas donde los efectos estresantes eran menores: los datos espectroscópicos no mostraron diferencias entre las 2 partes del dosel. A diferencia de la carente similitud con los resultados reportados por Wang y Sousa (2009), nuestros resultados son similares a los reportados por Zhang et al. (2014), quienes encontraron diferencias entre el mangle rojo y el mangle negro en longitudes de onda específicas en las regiones del verde $(520$ y $560 \mathrm{~nm})$ y del borde del rojo $(710 \mathrm{~nm})$. Sin embargo, hay una diferencia notable entre nuestros resultados del ADC y los de Zhang et al. (2014), ya que dichos autores no incluyeron muestras de mangle blanco y solo analizaron una estación del año.

Consideramos que la inclusión de la región del verde, junto con la del borde del rojo, puede ser de gran importancia para la clasificación óptima de un bosque de mangle 
2012), since chla concentration in leaves from the lower part of the forest canopy increases during the dry season as a result of photoinhibition in the upper part of the canopy. It was thus not surprising to find that the 3 species in the basin mangrove forest showed a high degree of separation between the upper and lower parts of the forest canopy. On the other hand, it has been suggested that species in fringe mangrove forests do not show differences in photosynthetic pigment contents between the dry season and the rainy season (Flores-de-Santiago et al. 2012), which was confirmed by our study using only spectroscopic data. This lack of separation has been suggested by Panigrahy et al. (2012) for healthy mangroves in India, where significant differences $(P<0.01)$ were detected along the electromagnetic spectrum in 4 tropical mangrove species.

Our results indicate that the fringe mangrove samples can be categorized into a single class for the spatial analysis with satellite imagery because they did not show differences between the upper and lower parts of the forest canopy. By contrast, basin mangrove samples, especially those collected during the dry season, may show high variability when classified on the basis of satellite images. This pattern is particularly due to differences in the tolerance to environmental factors (hydroperiod), which depends on coastal geomorphology (Saenger 2002). For example, in the American continent, Rhizophora grows along tidal channels where tidal influence is greater, whereas Avicennia generally grows in elevated areas where the hydroperiod is shorter (Monroy-Torres et al. 2015). This pattern is different in Asia, where Avicennia generally grows along tidal channels, followed by Rhizophora (Saenger 2002), whereas Laguncularia tends to not withstand sudden salinity changes and is intolerant to hypersaline conditions (Ridd and Stieglitz 2002). Our results indicate that spectroscopic analyses must be carried out locally to characterize regions of interest within the electromagnetic spectrum. These regions will depend on the physiognomy of each mangrove species and could minimize discrimination errors when classifying mangrove forests using satellite and RPAS images.

According to our results for this study, it is possible to separate mangrove species in 2 physiognomic types during 2 season in subtropical regions. Future studies must assess the feasibility of data obtained from satellite imagery and RPAS images by performing discrimination tests between mangrove species using the green and red-edge wavebands at the forest canopy level. In addition, we suggest using these wavebands to determine physiognomic types in mangrove forests. A certain degree of error is expected to prevail when processing hyperspectral data from satellite and RPAS images, as this study did not consider additional factors such as leaf angle, tree density, basal area, leaf area index, and water reflection in the forest (Zhu et al. 2017). We also suggest exploring novel algorithms derived from automated learning methods, such as partial least squares regression or random forests, to classify mangrove species at the canopy level. en ambientes subtropicales donde las condiciones ambientales no son favorables. La región del borde del rojo ha sido catalogada como una zona fundamental para la predicción de pigmentos fotosintéticos en hojas de mangle (Zhang et al. 2012, Flores-de-Santiago et al. 2016), así como para la discriminación de cobertura de bosque de mangle en el sureste asiático (Koedsin y Vaiphasa 2013). Aunado a lo anterior, los mangles tipo cuenca del sistema de Urías presentan un patrón temporal claro respecto al contenido de pigmentos fotosintéticos (Flores-de-Santiago et al. 2012), porque la concentración de chla en las hojas de la parte baja del dosel forestal incrementa durante la temporada de estiaje como resultado de la fotoinhibición en la parte superior del dosel. Como consecuencia, no fue sorprendente que las 3 especies de mangle tipo cuenca mostraran un grado alto de separación entre la parte superior y la parte inferior del dosel forestal. Por el contrario, ha sido sugerido que las especies de mangle tipo borde no presentan diferencias en el contenido de pigmentos fotosintéticos entre la temporada de estiaje y la temporada de lluvia (Flores-de-Santiago et al. 2012), lo cual se comprueba al utilizar solo datos espectroscópicos en nuestro estudio. Esta falta de separación ha sido propuesta con anterioridad por Panigrahy et al. (2012) para mangles saludables de la India, donde diferencias significativas $(P<0.01)$ fueron detectadas a lo largo del espectro electromagnético en 4 especies de mangle tropical.

Con base en nuestros resultados, las muestras de mangle tipo borde pueden ser catalogadas en una misma clase para el análisis espacial con imágenes de satélite debido a que no presentaron diferencias entre las muestras de la parte superior y las de la parte inferior del dosel forestal. Por el contrario, las muestras de mangle tipo cuenca, sobre todo aquellas recolectadas durante la temporada de estiaje, pueden llegar a presentar variabilidad elevada al momento de ser clasificadas con imágenes de satélite. Este patrón se debe, en particular, a diferencias en la tolerancia a factores ambientales (hidroperiodo), la cual depende de la geomorfología costera (Saenger 2002). Por ejemplo, en el continente americano, Rhizophora crece a lo largo de los canales de inundación donde la influencia de la marea es mayor, mientras que Avicennia generalmente crece en zonas elevadas donde el hidroperiodo es menor (Monroy-Torres et al. 2015). Este patrón cambia en el continente asiático, donde Avicennia por lo general crece a lo largo del canal de inundación seguida por Rhizophora (Saenger 2002), mientras que Laguncularia tiende a no soportar cambios bruscos de salinidad y es intolerante a condiciones hipersalinas (Ridd y Stieglitz 2002). Con base en nuestros resultados, los análisis espectroscópicos deben ser llevados a cabo de manera local para poder caracterizar las regiones de interés dentro del espectro electromagnético. Dichas regiones dependerán de las condiciones fisiognómicas de cada una de las especies de mangle y podrán limitar los errores de discriminación al momento de clasificar un bosque de mangle con imágenes de satélite y RPAS. 


\section{ACKNOWLEDGMENTS}

FFS received financial support for this study from the National Council for Science and Technology (Mexico, no. 198885), the General Directorate for Academic Staff Affairs at the National Autonomous University of Mexico (UNAM, for its acronym in Spanish) (no. 2017/ AS/00186/884715), and the Institute of Marine Sciences and Limnology (ICML, for its acronym in Spanish) at UNAM (no. 622). JMK received financial support from the Natural Sciences and Engineering Research Council (Canada, no. 249496-06). FFV received financial support from the ICML-UNAM (no. 323) for the field campaigns. Translation fees were covered by the ICML-UNAM.

English translation by Claudia Michel-Villalobos.

\section{REFERENCES}

Agraz-Hernández CM, García-Zaragoza C, Iriarte-Vivar S, FloresVerdugo FJ, Moreno-Casasola P. 2011. Forest structure, productivity and species phenology of mangroves in the La Mancha lagoon in the Atlantic coast of Mexico. Wetlands Ecol. Manage. 19(3): 273-293. http://dx.doi.org/10.1007/s11273-011-9216-4

Bannari A, Morin D, Bonn F, Huete AR. 1995. A review of vegetation indices. Remote Sens. Rev. 13(1-2): 95-120. http://dx.doi.org/10.1080/02757259509532298

Barbosa JM, Broadbent EN, Bitencourt MD. 2014. Remote sensing of aboveground biomass in tropical secondary forests: A review. Int. J. For. Res. 2014: 715796. http://dx.doi.org/10.1155/2014/715796

Biber PD. 2007. Evaluating a chlorophyll content meter on three coastal wetland plant species. Agric. Food Environ. Sci. 1(2): $1-11$.

Chen G, Azkab MH, Chmura GL, Chen S, Sastrosuwondo P, Ma Z, Dharmawan IWE, Yin X, Chen B. 2017. Mangroves as a major source of soil carbon storage in adjacent seagrass meadows. Sci. Rep. 7(1): 42406. http://dx.doi.org/10.1038/srep42406

Cochrane MA. 2000. Using vegetation reflectance variability for species level classification of hyperspectral data. Int. J. Remote Sens. 21(10): 2075-2087. http://dx.doi.org/10.1080/01431160050021303

Congalton RG. 1991. A review of assessing the accuracy of classifications of remotely sensed data. Remote Sens. Environ. 37(1): 35-46.

https://doi.org/10.1016/0034-4257(91)90048-B

Danson FM. 1995. Developments in the remote sensing of forest canopy structure. In: Danson FM, Plummer SE (eds.), Advances in Environmental Remote Sensing. John Wiley and Sons, Chichester (United Kingdom), pp. 53-69.

Dronova I. 2015. Object-based image analysis in wetland research: A review. Remote Sens. 7(5): 6380-6413. http://dx.doi.org/10.3390/rs70506380

Duke NC. 2016. Oil spill impacts on mangroves: Recommendations for operational planning and action based on global review. Mar. Pollut. Bull. 109(2): 700-715. http://dx.doi.org/10.1016/j.marpolbul.2016.06.082

Duke NC, Meynecke JO, Dittmann S, Ellison AM, Anger K, Berger U, Cannicci S, Diele K, Ewel KC, Field CD, et al. 2007. A world without mangroves? Science 317(5834): 41-42. http://dx.doi.org/10.1126/science.317.5834.41b
De acuerdo con los resultados de nuestra investigación, es posible separar especies de mangle en 2 condiciones fisiognómicas durante 2 temporadas en regiones subtropicales. Estudios posteriores deben evaluar la factibilidad de datos provenientes de imágenes de satélite y RPAS por medio de pruebas de discriminación entre especies de mangle utilizando las bandas verde y borde del rojo a nivel de dosel forestal. Además, se sugiere el uso de dichas bandas para poder determinar condiciones fisiognómicas dentro del bosque de mangle. Es de esperarse que prevalezca cierto grado de error al momento de procesar datos hiperespectrales provenientes de imágenes de satélite y RPAS, debido a que no se contemplaron en este estudio factores adicionales como el ángulo de las hojas, la densidad de los árboles, el área basal, el índice de área foliar y la reflexión del agua dentro del bosque (Zhu et al. 2017). Además, se sugiere la exploración de algoritmos novedosos derivados de métodos de aprendizaje automático, tales como la regresión de mínimos cuadrados parciales o los bosques aleatorios, para clasificar especies de mangle a nivel de dosel.

\section{Agradecimientos}

FFS agradece el financiamiento para esta investigación a través de apoyos otorgados por el Consejo Nacional de Ciencia y Tecnología (México, no. 198885), la Dirección General de Asuntos del Personal Académico de la Universidad Nacional Autónoma de México (UNAM) (no. 2017/ AS/00186/884715) y el Instituto de Ciencias del Mar y Limnología (ICLM) de la UNAM (no. 622). JMK agradece el financiamiento otorgado por el Natural Sciences and Engineering Research Council (Canadá, no. 249496-06). El financiamiento para las campañas de campo fue otorgado por el ICML-UNAM a FFV (no. 323). El costo de traducción fue cubierto por el ICML-UNAM.

Duncan C, Primavera JH, Pettorelli N, Thompson JR, Loma RJA, Koldewey HJ. 2016. Rehabilitating mangrove ecosystem services: A case study on the relative benefits of abandoned pond reversion from Panay Island, Philippines. Mar. Pollut. Bull. 109(2): 772-782.

http://dx.doi.org/10.1016/j.marpolbul.2016.05.049

Flores-de-Santiago F, Kovacs JM, Flores-Verdugo F. 2012. Seasonal changes in leaf chlorophyll $a$ content and morphology in a subtropical mangrove forest of the Mexican Pacific. Mar. Ecol. Prog. Ser. 444: 57-68.

http://dx.doi.org/10.3354/meps09474

Flores-de-Santiago F, Kovacs JM, Flores-Verdugo F. 2013a. The influence of seasonality in estimating mangrove leaf chlorophyll- $a$ content from hyperspectral data. Wetlands Ecol. Manage. 21(3): 193-207.

http://dx.doi.org/10.1007/s11273-013-9290-x

Flores-de-Santiago F, Kovacs JM, Flores-Verdugo F. 2013 b. Assessing the utility of a portable pocket instrument for estimating seasonal mangrove leaf chlorophyll contents. Bull. Mar. Sci. 89(2): 621-633.

http://dx.doi.org/10.5343/bms.2012.1032 
Flores-de-Santiago F, Kovacs JM, Wang J, Flores-Verdugo F, Zhang C, González-Farías F. 2016. Examining the influence of seasonality, condition, and species composition on mangrove leaf pigment contents and laboratory based spectroscopy data. Remote Sens. 8(3): 226. http://dx.doi.org/10.3390/rs8030226

Flores-de-Santiago F, Serrano D, Flores-Verdugo F, Monroy-Torres M. 2017. Application of a simple and effective method for mangrove afforestation in semiarid regions combining nonlinear models and constructed platforms. Ecol. Eng. 103(A): 244-255. http://dx.doi.org/10.1016/j.ecoleng.2017.04.008

Flores-Verdugo F, Ramírez-Barrón E, Flores-de-Santiago F. 2018. Hydroperiod enhancement using underground pipes for the efficient removal of hypersaline conditions in a semiarid coastal lagoon. Cont. Shelf Res. 162: 39-47. http://dx.doi.org/10.1016/j.csr.2018.04.008

Flores-Verdugo F, Zebadua-Penagos F, Flores-de-Santiago F. 2015. Assessing the influence of artificially constructed channels in the growth of afforested black mangrove (Avicennia germinans) within an arid costal region. J. Environ. Manage. 160: 113-120. http://dx.doi.org/10.1016/j.jenvman.2015.06.024

Friess DA, Webb EL. 2013. Variability in mangrove change estimates and implications for the assessment of ecosystem service provision. Global Ecol. Biogeogr. 23(7): 715-725. http://dx.doi.org/10.1111/geb.12140

Gilman EL, Ellison J, Duke NC, Field C. 2008. Threats to mangroves from climate change and adaptation options: A review. Aquat. Bot. 89(2): 237-250.

http://dx.doi.org/10.1016/j.aquabot.2007.12.009

Gitelson AA, Merzlyak MN, Grits Y. 1996. Novel algorithms for remote sensing of chlorophyll content in higher plant leaves. Geosci. Remote Sens. Symp. 4: 2355-2357. http://dx.doi.org/10.1109/IGARSS.1996.516985

Godoy MDP, de Lacerda LD. 2015. Mangroves response to climate change: A review of recent findings on mangrove extension and distribution. An. Acad. Bras. Ciênc. 87(2): 651-667. http://dx.doi.org/10.1590/0001-3765201520150055

Guo M, Li J, Sheng C, Xu J, Wu L. 2017a. A review of wetland remote sensing. Sensors 17(4): 777. http://dx.doi.org/10.3390/s17040777

Guo Q, Su Y, Hu T, Zhao X, Wu F, Li Y, Liu J, Chen L, Xu G, Lin $\mathrm{G}$, et al. 2017b. An integrated UAV-borne lidar system for 3D habitat mapping in three forest ecosystems across China. Int. J. Remote Sens. 38(8-10): 2954-2972. http://dx.doi.org/10.1080/01431161.2017.1285083

Heenkenda MK, Joyce KE, Maier SW, de Bruin S. 2015. Quantifying mangrove chlorophyll from high spatial resolution imagery. ISPRS J. Photogramm. Remote Sens. 108: 234-244. http://dx.doi.org/10.1016/j.isprsjprs.2015.08.003

Jensen JR. 2005. Introductory Digital Image Processing: A Remote Sensing Perspective. 3rd ed. Pearson Prentice Hall, New York, $526 \mathrm{pp}$.

Keuskamp JA, Hefting MM, Dingemans BJJ, Verhoeven JTA, Feller IC. 2015. Effects of nutrient enrichment on mangrove leaf litter decomposition. Sci. Total Environ. 508: 402-410. http://dx.doi.org/10.1016/j.scitotenv.2014.11.092

Koedsin W, Vaiphasa C. 2013. Discrimination of tropical mangroves at the species level with EO-1 Hyperion data. Remote Sens. 5(7): 3562-3582. http://dx.doi.org/10.3390/rs5073562

Komiyama A, Ong JE, Poungparn S. 2008. Allometry, biomass, and productivity of mangrove forests: A review. Aquat. Bot. 89(2): 128-137.

http://dx.doi.org/10.1016/j.aquabot.2007.12.006
Kuenzer C, Bluemel A, Gebhardt S, Quoc TV, Dech S. 2011. Remote sensing of mangrove ecosystems: A review. Remote Sens. 3(5): 878-928.

http://dx.doi.org/10.3390/rs3050878

Lichtenthaler HK, Gitelson A, Lang M. 1996. Non-destructive determination of chlorophyll content of leaves of a green and an aurea mutant of tobacco by reflectance measurements. J. Plant Physiol. 148(3-4): 483-493.

https://doi.org/10.1016/S0176-1617(96)80283-5

Lovelock CE, Cahoon DR, Friess DA, Guntenspergen GR, Krauss KW, Reef R, Rogers K, Saunders ML, Sidik F, Swales A, et al. 2015. The vulnerability of Indo-Pacific mangrove forests to sea-level rise. Nature 526: 559-563.

http://dx.doi.org/10.1038/nature15538

Martin TSH, Olds AD, Pitt KA, Johnston AB, Butler IR, Maxwell PS, Connolly RM. 2015. Effective protection of fish on inshore coral reefs depends on the scale of mangrove-reef connectivity. Mar. Ecol. Prog. Ser. 527: 157-165. http://dx.doi.org/10.3354/meps11295

Monroy-Torres M, Flores-Verdugo F, Flores-de-Santiago F. 2015. Growth of three subtropical mangrove species in response to varying hydroperiod in an experimental tank $=$ Crecimiento de tres especies de mangle subtropical en respuesta a la variabilidad en el hidroperiodo en un tanque experimental. Cienc. Mar. 40(4): 263-275.

http://dx.doi.org/10.7773/cm.v40i4.2455

Mukherjee N, Sutherland WJ, Dicks L, Hugé J, Koedam N, Dahdouh-Guebas F. 2014. Ecosystem service valuations of mangrove ecosystems to inform decision making and future valuation exercises. PLOS ONE 9(9): e107706. http://dx.doi.org/10.1371/journal.pone.0107706

Nagelkerken I, Blaber SJM, Bouillon S, Green P, Haywood M, Kirton LG, Meynecke J-O, Pawlik J, Penrose HM, Sasekumar A, et al. 2008. The habitat function of mangroves for terrestrial and marine fauna: A review. Aquat. Bot. 89(2): 155-185. http://dx.doi.org/10.1016/j.aquabot.2007.12.007

Nam VN, Sasmito SD, Murdiyarso D, Purbopuspito J, MacKenzie RA. 2016. Carbon stocks in artificially and naturally regenerated mangrove ecosystems in the Mekong Delta. Wetlands Ecol. Manage. 24(2): 231-244. http://dx.doi.org/10.1007/s11273-015-9479-2

Panigrahy S, Kumar T, Manjunath KR. 2012. Hyperspectral leaf signature as an added dimension for species discrimination: case study of four tropical mangroves. Wetlands Ecol. Manage. 20(2): 101-110. http://dx.doi.org/10.1007/s11273-011-9245-z

Pastor-Guzman J, Atkinson PM, Dash J, Rioja-Nieto R. 2015. Spatiotemporal variation in mangrove chlorophyll concentration using Landsat 8. Remote Sens. 7(11): 14530-14558. http://dx.doi.org/10.3390/rs71114530

Pettorelli N, Laurance WF, O'Brien TG, Wegmann M, Nagendra H, Turner W. 2014. Satellite remote sensing for applied ecologists: Opportunities and challenges. J. Appl. Ecol. 51(4): 839-848. http://dx.doi.org/10.1111/1365-2664.12261

Polidoro BA, Carpenter KE, Collins L, Duke NC, Ellison AM, Ellison JC, Farnsworth EJ, Fernando ES, Kathiresan K, Koedam NE, et al. 2010. The loss of species: Mangrove extinction risk and geographic areas of global concern. PLOS ONE 5(4): e10095. http://dx.doi.org/10.1371/journal.pone.0010095

Ridd PV, Stieglitz T. 2002. Dry season salinity changes in arid estuaries fringed by mangroves and saltflats. Estuar. Coast. Shelf Sci. 54(6): 1039-1049. http://dx.doi.org/10.1006/ecss.2001.0876

Saenger P. 2002. Mangrove Ecology, Silviculture and Conservation. Kluwer Academic Publishers, Dordrecht (The Netherlands), $360 \mathrm{pp}$. 
Sokal RR, Rohlf FJ. 2012. Biometry: The Principles and Practices of Statistics in Biological Research. 4th ed. W.H. Freeman and Company, New York, 937 pp.

Tian J, Wang L, Li X, Gong H, Shi C, Zhong R, Liu X. 2017. Comparison of UAV and WorldView-2 imagery for mapping leaf area index of mangrove forest. Int. J. Appl. Earth Obs. Geoinf. 61: 22-31. http://dx.doi.org/10.1016/j.jag.2017.05.002

Tomlinson PB. 1994. The Botany of Mangroves. Cambridge University Press, Cambridge, 413 pp.

Vaiphasa C, Ongsomwang S, Vaiphasa T, Skidmore AK. 2005. Tropical mangrove species discrimination using hyperspectral data: A laboratory study. Est. Coast. Shelf Sci. 65(1-2): 371-379. http://dx.doi.org/10.1016/j.ecss.2005.06.014

Valderrama-Landeros L, Flores-de-Santiago F, Kovacs JM, FloresVerdugo F. 2018. An assessment of commonly employed satellite-based remote sensors for mapping mangrove species in Mexico using an NDVI-based classification scheme. Environ. Monit. Assess. 190: 23. http://dx.doi.org/10.1007/s10661-017-6399-z

Villalba-Loera A. 1986. Descripción general del estero de Urías, Mazatlán, Sinaloa. Cienc. Mar (Mazatlan) 8: 32-37.

Wang L, Sousa WP. 2009. Distinguishing mangrove species with laboratory measurements of hyperspectral leaf reflectance. Int. J. Remote Sens. 30(5): 1267-1281. http://dx.doi.org/10.1080/01431160802474014
Wulder MA, Hall RJ, Coops NC, Franklin SE. 2004. High spatial resolution remotely sensed data for ecosystem characterization. BioScience 54(6): 511-521.

https://doi.org/10.1641/0006-3568(2004)054[0511:HSRRSD]2.0 .CO;2

Zhang C, Chen K, Liu Y, Kovacs JM, Flores-Verdugo F, Flores-deSantiago FJ. 2012. Spectral response to varying levels of leaf pigments collected from a degraded mangrove forest. J. Appl. Remote Sens. 6(1): 063501. http://dx.doi.org/10.1117/1.JRS.6.063501

Zhang C, Kovacs JM, Liu Y, Flores-Verdugo F, Flores-de-Santiago F. 2014. Separating mangrove species and conditions using laboratory hyperspectral data: A case study of a degraded mangrove forest of the Mexican Pacific. Remote Sens. 6(12): $11673-11688$. http://dx.doi.org/10.3390/rs61211673

Zhang C, Kovacs JM, Wachowiak MP, Flores-Verdugo F. 2013. Relationship between hyperspectral measurements and mangrove leaf nitrogen concentrations. Remote Sens. 5(2): 891-908. http://dx.doi.org/10.3390/rs5020891

Zhu Y, Liu K, Liu L, Myint SW, Wang S, Liu H, He Z. 2017. Exploring the potential of WorldView-2 red-edge band-based vegetation indices for estimation of mangrove leaf area index with machine learning algorithms. Remote Sens. 9(10): 1060. http://dx.doi.org/10.3390/rs9101060

Received June 2017, accepted August 2018. 